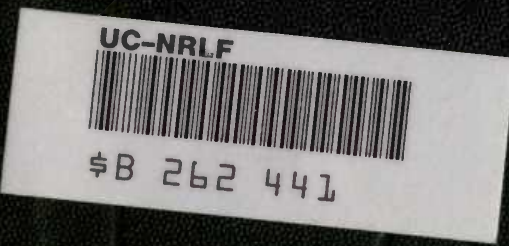




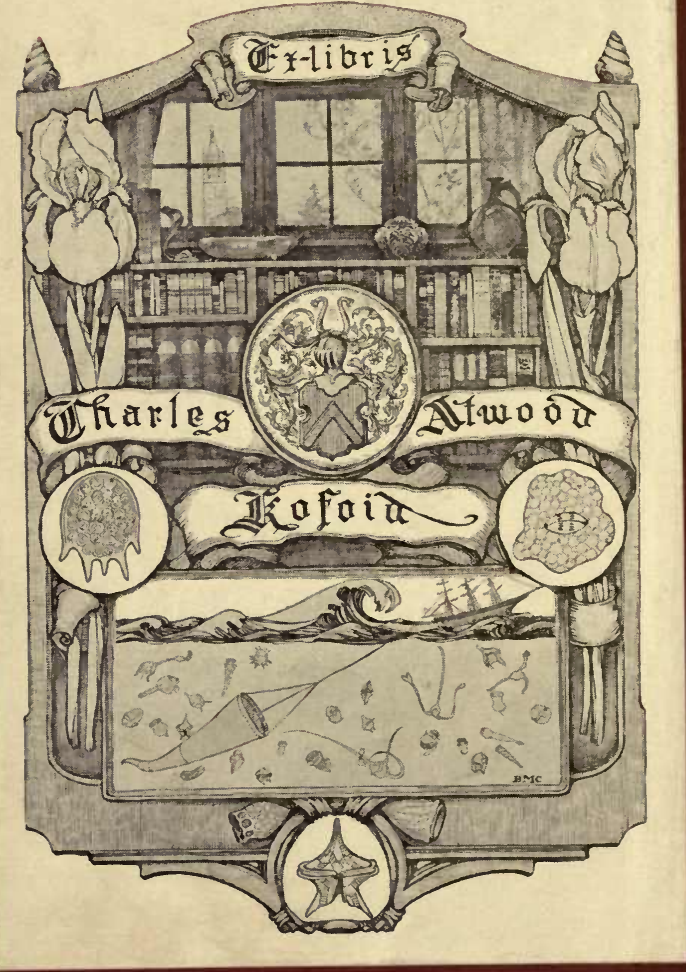




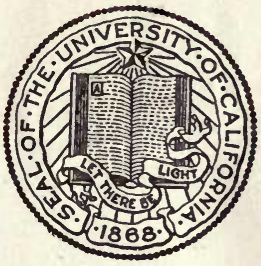

THE LIBRARY OF

THE UNIVERSITY OF CALIFORNIA

PRESENTED BY PROF. CHARLES A. KOFOID AND MRS. PRUDENCE W. KOFOID 


$$
4
$$



- 
H O R S E

AND

M A N. 
LONDON : PRINTED BY SPOTTISIVODE AND CO., NEW-STREET SQUARR AND PARLIAMENT STREET 


\section{HORSE AND MAN.}

BY

- C. S. MARCH PHILLIPPS,

AUTHOR OF 'JURISPRUDENCE' ETC.

'Si je n'avais rien à dire de nouveau, je ne prendrais pas la peine d'écrire.'

BAUCHER.

LONDON :

L O NGMAN, GREEN, AND CO. I869. 


\section{SF 309}

INTRODUCTION.

The PRINCIPAL OBJECT of this little work is to make the English sportsman acquainted with the rudiments of $M$. Baucher's admirable system of Suppling the Horse.

It is now about thirty-five years since $M$. Baucher first laid his theory of equitation before the French public. Its merits have been long and keenly discussed upon the Continent, but I cannot find that it has ever attracted any serious notice in England. An English pamphlet, containing an outline of its principles as adapted to the training of cavalry horses, was indeed published by the late lamented Captain Nolan in 1853 ; but it was not calculated to attract, and certainly did not receive, much attention from civilian horsemen.

I have not thought it advisable to translate 
any part of M. Baucher's works. Like many men of original genius, he was far more successful in discovering truth than in explaining it. His style of disquisition is very prolix, and sometimes not a little obscure; indeed there are certain portions of his teaching whose precise object and connection I frankly acknowledge myself unable to comprehend. Nor is this all. He perpetually employs that peculiar tone of philosophical grandiloquence which is so dear to French writers, and so utterly intolerable to English readers. I question whether there are many of my hunting acquaintance who would patiently hear themselves admonished that the cavesson must be 'sustained with an energetic wrist,' or that the horse must be prevented from 'taking an initiative which might have its dangers.'

But it has occurred to me that I may be able to do good service by introducing to the civilian horseman those elementary principles of M. Baucher's system which Captain Nolan has judged likely to be useful in the military riding-school. My own observation has con- 
vinced me that they may be made exceedingly serviceable in the education of ordinary horses, and that they are entirely unknown to, or neglected by, ordinary horsemen. I have therefore endeavoured to explain them in a simple and straightforward manner, as I find them laid down by M. Baucher himself; and I have also stated the opinion which experience has led me to form of their practical utility or necessity, in the hope that better judges may possibly be induced to give them an equally fair trial.

All Englishmen naturally hate theory; and perhaps no Englishman hates it so thoroughly as an English sportsman. The fact is, in my opinion, highly creditable to the English intellect. Practical men are quite justified in hating a thing of which, potentially beautiful and admirable as it may be, they have never met with any specimen that was not actually useless or pernicious. And just as English statesmen despise a theory of government which practically leads to slavery or to anarchy, even so do English horsemen despise a 
theory of equitation which practically disables its professors from riding across country. Your conclusions, we say, may be true in theory, but they are false in practice; and this familiar platitude is by no means so absurd as it sounds. Its real meaning is: We do not think it worth while to prove by argument that your theory is false, because experiment has convinced us that it cannot possibly be true.

But I do not observe that, when Englishmen have once perceived the practical value of a theory, they are either incapable or impatient of the abstract reasoning necessary to explain its principles. The kind of theory which we despise is that which is founded upon ingenious assumption unverified by experiment. Experiment is therefore our first demand. Show us your results, we say, and if we like them we will try to understand your demonstration. And how faithfully we in this respect keep our word, nobody who has ever been intimate with an enthusiastic rifleman or yachtsman requires to be reminded. 
I persuade myself that $M$. Baucher's system is one which will stand this test. The simple and obvious method of manipulation by which it imparts lightness and elasticity to the dull, or calmness and docility to the fretful horse, can be tried without the slightest difficulty by any practised horseman; nor do I believe that any practised horseman who fairly tries it will deny its efficiency. That I neither profess to be an accomplished master of its resources, nor an implicit believer in the magical properties which some of its admirers ascribe to it, will appear hereafter. But I am convinced that its elementary lessons may be employed with perfect ease, and with most satisfactory effect, by any man who has an awkward hack which he wishes to make a clever one.

I have however, in the present work, attempted something more than this. I must confess that I have never seen any book upon horsemanship which I thought likely to be useful to a beginner. The old treatises on manége-riding, being founded on 
a false theory, are of course wholly out of the question. The modern English manuals, though far more rational and correct, have all one great deficiency. They are invariably written by men who have evidently been practised horsemen from their childhood. How can such a man realize the difficulties of a novice? He tells us what we ought to do; but if we were to suggest that we cannot do it, he would listen as if we were complaining that we cannot help stammering or squinting. It is very singular and very unfortunate; he cannot account for it; he has been performing these manœuvres all his life, and never found them puzzling or difficult.

Now I am well aware that most of these gentlemen know much more of good riding than I do, but I flatter myself that I know more of bad riding than they do. Circumstances induced me, when in the prime of life, to take pains enough to become a fair mechanical horseman; and the difficulties of the achievement are therefore fresh and vivid in my memory. The method which I have 
found most effectual for the purpose is a simple adaptation of the system which $M$. Baucher applies to the education of the horse. In other words, it consists in learning one thing at a time. This method I have taken the present opportunity briefly to explain. It is, I need scarcely remark, exclusively intended for the use of inexperienced horsemen: It cannot change a good rider into a first-rate one; but I believe that, if perseveringly and intelligently practised, it will enable a bad rider to become a tolerable one.

One word more. The present work is a treatise upon mechanical equitation, and upon that alone. Upon the mystery of riding races, or of riding to hounds, I have not a word to say. ' Riding across country,' said the renowned Meynell, ' requires three things -head, heart, and hand '; in other words, judgment, courage, and horsemanship. Mere mechanical horsemanship - that is to say, the mere knack of making your horse do what you please-is therefore far from sufficient to distinguish you in the field. It will not 
teach you what to make him do, nor prevent you from being afraid to make him do what is required. Now mere horsemanship, and a comparatively humble degree of mere horsemanship, is all that I can show you how to acquire. The higher qualities of the English sportsman must be learnt, if they can be learnt at all, from teachers more experienced in their practice than I can pretend to be.

February 16, 1869. 


\section{CONTENTS.}

INTRODUCTION

\section{CHAPTER I.}

THE SEAT.
1. Position on Horseback .
2. Fixing the Legs
3. Suppling the Waist .
4. Riding with Stirrups

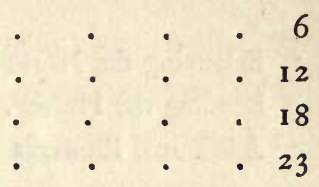

\section{CHAPTER II.}

THE HAND.

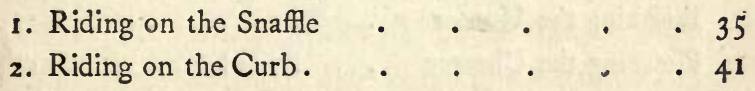

\section{CHAPTER III.}

THE LEGS.
1. Working in Line
2. Working Sideways . 


\section{CHAPTER IV.}

THE NERVES.

I. Sitting a Restive Horse . . . . 66

2. Managing a Restive Horse . . . 72

CHAPTER V.

BREAKING THE HORSE . • 78

\section{CHAPTER VI.}

SUPPLING THE HORSE.

1. Balancing the Horse . . . 89

2. Bending the Horse . • . . . 96

3. Additional Remarks . . . . 104

\section{CHAPTER VII. \\ FINISHING THE HORSE.}

\section{Finishing the Hunter}

2. Finishing the Charger

ConCLusion 


\section{HORSE AND MAN.}

\section{CHAPTER I.}

THE SEAT.

UPON no subject has more consummate nonsense been talked or written than upon the best method of acquiring a good seat on horseback. In fact, the highest authorities have fairly renounced the task of suggesting any method at all, and seem to hold that horsemanship, like reading and writing in the opinion of Master Dogberry, comes by nature. The once celebrated Nimrod pronounces that no man whose thighs are round, or whose calves are large, can ever ride well; and a far better judge, the clever writer who signs himself 'Harry Hieover,' has indorsed the vulgar opinion, that no man can become a horseman who has not been used to riding from his 
childhood. It is quite time that these prejudices, so derogatory to the science of equestrian and to the spirit and intelligence of pedestrian Englishmen, should be resolutely protested against.

It is undoubtedly true that not one man in a hundred ever does learn to ride well, unless he has ridden early in life. But why is this? Simply because full-grown men seldom acquire new tastes in amusement, and therefore do not care to ride well when they have not been accustomed to ride at all. It does not follow that they could not learn to ride, if good riding were necessary to their safety or convenience. Indeed the reverse is the fact. We are told that shopmen and mechanics, when settled upon an Australian or Californian cattle-farm, soon learn to imitate the gymnastic feats of the stockmen or vaqueros around them; and we know that if a hundred clerks or apprentices are enlisted in a dragoon regiment, ninety-nine of them will in six months sit their horses quite as firmly as an ordinary groom or postboy,

This, however, is understating our case. Horsemanship is in these instances acquired 


\section{The Seat.}

by mere mechanical practice or by an unscientific system of teaching which is very little better. What will be the consequence if a grown man, being anxious to become a horseman, can be shown how to use, not only his limbs and muscles, but his reason and memory for the purpose? I answer that in a month he will be perfectly easy upon an ordinary horse, and that in three months he will possess as perfect a seat as his natural aptitude for riding would have permitted him to acquire if he had passed his whole life in the saddle.

How, it may be asked, is this to be done? I answer, simply by attending to one thing at a time. You want to learn how to sit a horse. Very good; then put aside for the present all anxiety about managing and guiding him. Your present business is, wherever he may go and whatever he may do, to continue steady upon his back. Therefore leave it to some one else to take care that he goes where he ought and does nothing which he ought not. You are at present in the situation of a landsman going to sea, and must not think about steering until you have got your sea legs. 
You have only to take a lesson in an ordinary riding-school to learn how necessary this advice unfortunately is. Your instructor first screws you by main force into what is to you a most unnatural position, and next gives you certain instructions which you cannot understand. In this state of bodily and mental discomfiture you walk twice or thrice round the school, and then your troubles begin. ' Trot. Steady, Mr. So-and-so. Keep him in hand. Guide him into the corners. Don't let him canter. A little faster. Press him with the legs. Touch him with the whip. Too fast. Pull him up. Halt-halt-halt! Never mind, Sir; mount him again-you will soon catch the knack of it.' And so no doubt you would, if you were allowed to catch one knack at a time; but half-a-dozen simultaneous catches are too much for human dexterity.

Take the advice of an old sportsman. Single out your bird, and bring it down. Let the rest of the covey fly-you shall have a fair shot at each in its turn, before you have done with them. Get a docile old horse, with a well-made saddle; and choose as your 
assistant a groom who has his wits about him, but over whom you have complete authority. Have your mount led into a field or paddock, if you have not access to a riding-house; and there, forgetting all other cares and considerations whatever, fix your whole attention upon the single object of keeping steadily and comfortably astride upon your saddle.

I say keeping astride your saddle, because I intend to let you get into it and out of it as you can. You are probably acquainted with the ordinary method of mounting and dismounting; and if you are not, you can easily find it out for yourself. The only advice I have to give you is to acquire the habit of getting on and off your horse as smoothly and quietly as possible. I ought, however, to mention, that $\mathrm{M}$. Baucher recommends the horseman to seize the pommel of the saddle before he springs from the ground, instead of laying his hand upon the cantle and shifting his grasp as he throws his leg over. The suggestion, so far as I can venture to judge of it by my own experience, is one of little importance. 
I. Position on Horseback. - As the art of riding is divisible into the art of sitting your horse and the art of controlling him, so the art of sitting your horse is subdivisible into the art of taking your seat and the art of keeping it. Begin by finding out the safest and firmest position which the human frame can assume upon horseback. Place yourself in this position, and exercise yourself until it has become perfectly comfortable and familiar to your body and limbs. Persevere in quitting and renewing it until you drop into it as naturally as into an easy chair. When you have done this, you may proceed to enquire how you can best prevent the position thus acquired from being disturbed by the movements of the horse.

It is commonly said that the best and firmest position on horseback is the most natural; and this is in one sense perfectly true. But the word natural is often loosely used, and therefore easily misunderstood. The best and firmest position on horseback is undoubtedly that which is natural to the human frame when in its proper state, and therefore that which ought to be natural to every human 
being. But we know too well that the frame of an ordinary human being is by no means in its proper state, and will often be unpleasantly strained and wearied by a position which would be perfectly natural to a well-trained athlete. And it is therefore probable that an ordinary human being may require some instruction before he can assume, and some gymnastic discipline before he can with comfort retain, the position on horseback which experience shows to be the most secure, and which an accomplished horseman would no doubt pronounce to be the most natural.

The position on horseback recommended by experience may be described as follows. The horseman's fork - that is to say, the space between his thighs - must rest upon the centre of the saddle, and support the full weight of his body. The necessary consequences will be, that the flat or inner surface of his thighs will lie along the saddle-flaps, that his spine will be hollow or concave at the waist, that his chest will expand itself, that his shoulders will fall back, and that his head will stand erect upon his neck. The arms and hands, in the absence of reins, and the legs and feet, 
in the absence of stirrups, may be suffered to hang down in the postures assigned by their weight.

Now this position may be perfectly natural to a strong well-made young man, thoroughly inured to athletic exercise; but it will prove exceedingly irksome to a middle-aged gentleman of sedentary habits, long accustomed to divide his existence between lying in a bed, stooping over a desk, lounging in a chair, and plodding along a pavement. The position which such a person will find the most easy and comfortable, when first placed on horseback, will be very different from that just described. He will probably rest his weight upon his seat behind the thighs, with his back curved, his shoulders drooping forward, his knees elevated, and his feet advanced. And, if induced by his instructor to assume a better attitude, he will go home with his spine and thigh-joints aching as if dislocated, and with his mouth full of indignation at the pedantry which forbids him to use his limbs and muscles in the manner designed by Providence.

The mistake made by such a pupil is easily explained. He objects to the position on 
horseback which he is required to assume, because, whatever may be its other advantages, it is painful and fatiguing. How can he possibly tell at present whether it is necessarily fatiguing or not? He has all his life been standing and walking with his backbone convex and rigid, and it is no wonder that he now feels uneasy when it becomes concave and supple. If he had been hopping all his life upon one leg, he would have felt uneasy when he began to stand or walk upon two. Before he can judge whether the upright or the stooping position on horseback is really the easiestthat is to say, which of the two is capable of being longest maintained without fatiguehe must first become equally familiar with both.

This may, to a considerable extent, be effected on foot. Begin by using the ordinary gymnastic means for suppling the shoulders and loins. Stand erect; and work the hips laterally at every possible angle, permitting the bust to fall loosely in whatever direction its weight may draw it. Stretch and exercise the muscles of the chest and shoulders by using the clubs or dumb-bells, or by practising 
the military extension-motions. In a very few days you will find, if you are in tolerable health and strength to begin with, that you naturally stand and walk with your waist dropping in and your bust expanded. Then get on horseback again. You will immediately become aware that you have taken a considerable step in advance. The flexure of the loins which is necessary to combine the proper positions of the fork and bust, is no longer irksome. In other words, you have no longer any physical uneasiness in sitting your horse as you ought.

But, above all things, do not permit yourself to shirk this preliminary difficulty. Be assured that it is a difficulty, and that it must be fairly faced and conquered. The fork home on the saddle, and the bust poised upon the fork, are the indispensable conditions of a good seat on horseback; and they cannot be united without hollowing the waist to a degree which most men will find at first exceedingly tiresome. Work patiently on until it ceases to be so. You will be well rewarded for your trouble. It is this position, correctly taken and skilfully kept, which gives fine riders that 
peculiar air commonly described as forming part of the horse. They may, from carelessness or affectation, have ungraceful peculiarities; but the poise of their bodies is always perfect. In fact nothing is more curious than to watch how the trunk of a skilful but slovenly horseman appears to grow out of his horse's back, while his legs are working and swaying like mere appendages.

Look, for instance, at Leech's admirable caricature, in Mr. Sponge's Tour, of Lord Scamperdale riding over to dine at Jawleyford Court. The noble lord is represented as a square, thickset, ungainly man, dressed in a style of flashy vulgarity; and nothing can be more grotesque than the jockey-like affectation with which he is lowering and spreading his hands, or than the pseudo-military affectation with which he is stretching down his short legs, and cocking up his large feet. But all these absurdities are forgotten at once, when we observe the commanding ease with which his hody is planted in the saddle. The great artist knew better than to trifle with that part of his hero. The horse, a remarkably clever white galloway, is striding 
away at a slashing hand-gallop; and the rider carries his bust and head like an ugly, vulgar centaur. Lord Scamperdale is certainly an ill-dressed and ill-looking man, but there is no mistake about his being a consummate horseman.

You now know how to sit properly in your saddle, and are beginning to feel tolerably comfortable while doing so. Next learn to resume your seat quickly and naturally whenever it is disturbed. Have your horse led about at a walk. Throw yourself into every irregular attitude you can think of. Swing your body backwards and forwards, shift your seat from side to side, sway and stretch your thighs and legs; and return, after every change of posture, to your original position. When you can do this with a single, quick, smooth, easy movement, you know how to take a good seat on horseback. All that remains is to find out the best way of keeping it.

2. Fixing the Legs.-There are good judges who maintain that the art of keeping your seat on horseback is simply the art of 
balancing your body according to the movements of the horse. This, however, is not my opinion. I acknowledge that there are horsemen who, by the help of a perfect balance and a perfect hand, can ride almost any horse with almost perfect safety. They can do this because their exquisite tact enables them to foresee any movement which the horse can make, and to prevent or follow any movement which they can foresee. But few men can acquire such skill as this, and even those who possess it may occasionally be caught off their guard. I therefore advise the equestrian novice to take some pains for the purpose of acquiring a kind of seat which will enable him to resist such shocks as he may be unable to foresee.

The celebrated Assheton Smith is said to have been a horseman of this kind. $\mathrm{He}$ is described as galloping across country, his body perfectly poised, and his legs flapping loose with his horse's stride. The consequence was, that a blunder at a fence was pretty sure to throw him from his saddle, and that, when taken unawares, he was sometimes unhorsed by a start or a plunge. It is true 
that, to a man of his hardihood and agility, such accidents were jokes. $\mathrm{He}$ was never hurt, he never lost his horse, and he always escaped the only danger for which he cared a farthing - that of being crushed or kicked on the ground. 'A fall,' he used to say, ' is nothing to me; it is you fellows with the sticky breeches that get nipped under your horses.' But it is not every man who can contemplate with so much philosophy a flight over the head of a sixteen-hands hunter.

If you wish to keep your seat in an unexpected shock, you have only one course to pursue. You must acquire the knack of firmly grasping your saddle with your legs. Nothing else will do. A good horseman can no doubt, when he knows what his horse is going to do, place himself in an attitude which will preserve him from receiving any shock from the movement. But this attitude will nut always be the same. There is no one attitude in which you can, without the aid of force, be prepared for whatever irregular movement your horse may choose to make. You must therefore learn, in order to be secure on horseback, either to employ the aid of force, 
or to foresee all your horse's movements; and the former alternative, I need scarcely add, is much the easier of the two.

What, then, ought to be your first step? Look at a cookmaid skinning eels. She knows that the strongest man in England could not effectually grasp an eel with a slippery hand, and therefore she commences operations by carefully sanding her fingers. You know, or if you choose to try you will soon find out, that the strongest pair of legs cannot, if clad in cloth overalls, effectually grasp a leather saddle. Begin, therefore, by clothing your legs in leather. Breeches and top-boots are, or used to be, the characteristic garb of the English horseman; but the Napoleon legging will be found, by those who dislike the trouble of changing their dress whenever they ride, as adhesive to the saddle and almost as neat to the eye.

Grasping with the legs may appear a very simple exercise of muscular force; but there is a right and a wrong way of doing everything, and you will stick much more tenaciously to your saddle if you begin by finding out the most effectual method of applying your 
strength for the purpose. Remember then, first that the grasp of the fore part of the leg is more adhesive than that of the back part, and secondly that the grasp of the upper part of the leg is more adhesive than that of the lower part. Remember also that, the more precisely under your weight your legs embrace your horse's body, the less power he will have to shake off their hold. The attitude in which you can clip your saddle most vigorously will consequently be the following. Keep your fork resting upon the centre of the saddle, your weight resting upon your fork, and the flat of your thighs lying along the saddle-flaps; then place your feet horizontally, and draw back your legs until your toes are vertically beneath your knees.

By maintaining this position you will effectually avoid two fatal blunders. Some novices endeavour to obtain a firm gripe by stooping forward and doubling up their legs behind them. Others sit far back, carry forward their feet, and rest their knees against the padding of the saddle-flaps. Both errors are quite inconsistent with good riding; but the former, as being the more obviously and 
absurdly so, is the less dangerous of the two. You cannot crouch with your back and cling with your heels, without becoming conscious at once that you are thoroughly at your horse's mercy. But the oblique seat, though necessarily always imperfect, is quite consistent with a considerable degree of ease and firmness in the saddle, and is therefore retained, if not recommended, by many horsemen whose experience ought to have taught them better.

Some of our equestrian artists are in these particulars sad misguiders of youth. They appear to think that a good horseman keeps his seat over a large fence by embracing his horse's barrel with the calves of his legs drawn backwards until they slant from the saddlegirths to the stifle-joints. No equestrian figures can for instance, as a general rule, be more elegant than those of Mr. Hablot Browne; but he cannot free himself from this inveterate delusion. Look at his illustrations of Mr. Lever's popular tale, 'The O'Donoghue.' How admirably poised in his saddle is the horseman who is forcing his rearing steed into the surf; and what a contrast does he present to the tailor who, with legs gathered up and 
tucked under him like those of a cockney making his first attempt at the leaping-bar, is compelling his unfortunate mount to smash a five-barred gate.

When you understand how to grasp your saddle with your legs, you will find a little practice very useful in suppling and strengthening the muscles which you have to use for the purpose. Take your gripe deliberately, and then try its strength by abandoning your balance. Throw your body backwards, or sway it from side to side, and watch how heavy a strain the tenacity of your thighs and legs is able to support without slipping. Next sit loosely, let your body fall backwards or sideways, and stop its fall by catching the saddle with your legs. You will, after a very few days of this exercise, become conscious of a surprising increase in the ease and power of your adhesion to your horse.

3. Suppling the Waist.-A good seat on horseback may be defined as the knack of grasping the saddle firmly with the legs without disturbing the position of the body. You have now learnt how to place the body, and 
how to grasp with the legs. You must next learn how to combine the two actions while the horse is in movement. The combination will at first be a matter of some little difficulty. You will soon find, or fancy you find, that you can exert the muscular force of your legs more powerfully when your waist is allowed to become round and stiff than when it is kept hollow and pliant. You will therefore be tempted to increase the tenacity of your gripe at the expense of losing the regularity of your position. This temptation you must resolutely and successfully resist.

For this purpose you must first of all realise the truth, that no muscles ever bestowed upon man can possibly keep you secure in your saddle, so long as your spine is allowed to be rigid at the waist. The grasp of your legs, well placed and steadily exerted, is sufficient to keep your body from the hips downwards from being dislodged by the movements of your horse, however violent they may be. But the result will be otherwise if, by stiffening your back-bone, you allow the additional weight of your bust to be abruptly thrown upon the support of your femoral gripe. You 
must therefore, unless you wish to be constantly jerked or twisted out of your seat, learn to keep your waist pliant while you keep your legs fixed.

So long as your horse stands still, or only moves at a walk, you will have no difficulty in maintaining any position on his back which you may choose to assume. You must, therefore, in order to acquire the knack of keeping your balance, venture upon a trot or a canter. For this purpose, place yourself in your proper position and take a steady grasp of your saddle. Let your reins hang quite slack, and do not use your stirrups. Thus prepared, let your assistant put your horse into a gentle trot. Leave the management of the animal entirely to him, and attend to nothing but keeping your seat as firmly as possible.

The first difficulty to be mastered for this purpose is that of keeping your waist hollow and your shoulders back. It is a difficulty to which you have no excuse for yielding, because it is one which you can vanquish by main force. When your horse is about to strike a trot, resolve that nothing shall induce 
you to relax the position in which you place yourself. If you cannot keep your spine concave without stiffening it, stiffen it by all means. Set yourself to endure, with patient fortitude, the bumps and thumps which undoubtedly are (in a metaphorical sense) before you. In a very short time the involuntary rigidity of the muscles will begin to relax, and the waist will regain its easy play. without relinquishing its necessary flexure.

When this is the case, the first great obstacle to your progress has fairly begun to give way. You have now acquired the foundation of a good seat, and require nothing but practice to make it perfect. Persevere in trotting without stirrups, making your attendant increase the action of your horse as you find yourself firmer and easier in the saddle. When you are quite easy at a full trot, let him halt and make your horse circle round him to the right and left. Do not be satisfied until, by combining the steady grasp of the legs and the supple play of the spine, you are able to stick to the roughest goer as if you were part of, the saddle. Three weeks 
or a month of hard drudgery will be amply rewarded by such a result.

Your assistant may now put your horse into a steady canter. You will find this pace much easier to sit than the trot, but not at first easier to sit well. The action of the horse no longer jolts you from side to side; it tends to tilt you upwards and forwards. This sensation will at first make you stiffen yourself without being conscious of it; and you will be tempted to mitigate your consequent concussion upon the saddle, not by the difficult though effectual expedient of keeping your waist concave and making it supple, but by the easy though imperfect makeshift of allowing it to remain stiff and become convex. You have only to do as you did in learning to trot. Keep your waist concave by force, and allow it to become supple by degrees; and you will soon experience the delightful sensation of sailing along at full gallop without stirring in your saddle.

When you can sit your horse perfectly in his trot and canter, you possess a seat such as not one rider in half-a-dozen ever acquires. You are still far from being a good horseman. 
You cannot indeed, properly speaking, be termed a horseman at all. But you may look forward with confidence to becoming what most men would consider an excellent horseman; because you have had the patience and perseverance to drudge on until you have been bumped and jolted into a smooth and solid union with your saddle. It is by the absence of this union, and by the abrupt shocks and displacements to which they are consequently exposed, that so many riders are disabled from acquiring the proper use of their hands and legs, and consequently from ever becoming masters of their horses.

4. Riding with Stirrups.-You have hitherto ridden, if not altogether without stirrups, at least without making any perceptible use of them; and your experience has, I trust, convinced you that a perfectly firm seat may be acquired without their assistance. If, in fact, a good horseman rides more securely with than without stirrups, this is not because they help him to keep his seat, but only because, if he should happen by any accident to lose it, they enable him to recover it with ease and 
quickness. This, however, is not all. Stirrups are of the greatest use in making the horseman's seat easy and comfortable, and in enabling him to ride fast and long without fatigue. The proper method of using them ought therefore to be carefully practised by every equestrian novice.

Even at a walk the assistance of stirrups is far from unimportant. You will soon find it intolerably wearisome to keep your thighs and legs always grasping the saddle; not only because the muscles thus used will become tired, but because by fixing yourself in your seat you greatly increase the play of your waist and loins with the action of the horse. You will find it almost equally fatiguing to let your legs dangle loosely in the position determined by their weight. But by stretching down your heels and pressing the stirrups steadily with your feet, you will not only relieve the limbs themselves, but will prevent your body from incessantly writhing and working as the horse steps along.

At a trot-at least at a full trot-the use of stirrups is almost indispensable. Without them the fatigue of the steadiest horseman 


\section{The Seat.}

would soon become intolerable, not only because he would have no means of avoiding the incessant shock of the horse's action, but also because he could not depart from his regular position in the saddle, except at the risk of being immediately unseated. With them a free and elastic trotter becomes the best and pleasantest of hacks. Well poised in his stirrups, and rising corkily to the stroke of his lively nag, the practised horseman can support his body in almost any attitude which he may find corvenient, and can thus ride a day's journey without any unpleasant exertion.

At the gallop the stirrups are seldom employed. But this is only because, in ordinary riding, the horse is seldom galloped very fast or very long. When this becomes necessary, as in hunting it often does, the rider will soon find the incessant spring and pitch exceedingly jarring. In this case let him incline his body forward, lower his hands upon the horse's withers, and press the stirrups steadily with his feet. At first he will undoubtedly feel his new position somewhat precarious. But after a little practice he will find that it en- 
tirely relieves his fatigue. His seat will part from and return to the saddle with a gentle oscillation as the horse strides along, but the alteration of his balance will remove all disagreeable concussion from the contact.

Let the length of your stirrups be entirely determined by the natural position of your legs while grasping your saddle. Take your gripe, with your thighs at the angle most convenient for tenacious adhesion, your legs vertical from the knee downwards, and your feet drooping easily from the heel to the toe. Then regulate the stirrup-leathers so that the irons shall touch, just enough to keep them steady, the hollow of the foot. You will thus be sure that your stirrups are long enough not to interfere with your position when you do not want their assistance, and short enough to give you full support when you do. Feel the stirrup-iron with the hollow or the ball of the foot as you please; remembering only that, if you prefer the latter posture, the instep must be carefully kept pliant when you are not pressing upon your stirrups.

You will easily divine from this advice that I am, as to one favourite article of the ordi- 
nary equestrian creed, a complete heretic. I am utterly unable to understand why different positions on horseback should be adopted by different descriptions of horsemen. Every horseman, I humbly conceive, wishes to be as firm and as easy in his saddle as he possibly can. If one position of the legs is found the most effectual for this purpose by the jockey, why should another be found more so by the dragoon? or how can we persuade ourselves that an attitude, which would be insecure if the horse were to charge an ox-fence, is secure when he is charging a square or a battery?

The oldfashioned military and the oldfashioned hunting seats were both, in my opinion, more or less mistakes. In the former the thighs were stretched almost vertically downwards, so that it became impossible to grasp the saddle below the knee. In the latter they were raised almost horizontally forwards, so that it became impossible to grasp the saddle above the knee. In both, therefore, the position of the rider was materially less secure than it would have been if they had been allowed to lie in their natural 
attitude. I believe, moreover, that the best judges are now of the same opinion, and that there is no longer any really important difference between the seat of an average fox-hunter and that of an average dragoon.

I know that there are certain mysteries of jockeyship which may possibly require, for the convenience of the horse and not of the rider, a peculiar attitude in the saddle. I also know that, if a horseman's body is but perfectly poised, there is no conceivable position into which he may not, with comparative security, torture his lower limbs. There were fine horsemen in the antique manege, where the legs of the cavalier were placed like a pair of tongs; and there are fine horsemen now in India, whose legs are placed like those of a tailor at work. But remember that, if such seats can be made secure, they must be so by what would otherwise be a superfluous nicety of balance. The rational horseman will place his body and legs so as to assist each other as much as possible, instead of having to correct the awkwardness of the one posture by the extraordinary excellence of the other.

Whoever wishes to find the true model of 
universal horsemanship, has only to look at the equestrian figures of Grecian sculpture. Nothing can be more delightful to the eye of a horseman than the beautiful relics of ancient art which compose the Elgin Marbles. One is never weary of admiring that long procession of graceful cavaliers, each seated in the finest possible position, yet each having an individual character of his own; their thighs and knees riveted to the horse's girth, their easily drooping legs and feet, their supple waists, their expanded and recumbent busts, their neatly poised heads, their hands and arms playing lightly with every movement of the bridle. It is almost annoying to think that such godlike equitation was thrown away upon the stag-necked, hammer-headed, hogmaned cobs which seem to have been the only inmates procurable for the classical stable. 


\section{CHAPTER II.}

THE HAND.

You are now perfectly firm and easy on your horse in his regular paces, and tolerably confident that no irregular movement which he is at all likely to make will disturb you in your saddle. In other words, you have acquired a pretty good seat. But you are still very far from being a good horseman. So far, indeed, that you are likely, if you now stop short in your education, to become a singularly clumsy and dangerous horseman; because you have acquired strength and confidence without acquiring skill. In fact, the only conceivable objection to the plan of teaching horsemanship by successive steps is the possibility, that the pupil may be so perverse as to think the first step sufficient. The novice who studies seat and hand together is at least kept out of premature risks by his instinctive fear of falling off; but no man is so likely to kill his horse 
and hurt himself, as a bold and firm rider who has never learnt to manage his bridle.

The principle upon which the horse is controlled by the bridle is a very simple one. No horse can, or at least no horse will, execute any pace without stretching and relaxing his neck or crest in time to the action of his legs. If, therefore, we can restrain this movement of the horse's crest, we disable him from advancing by moving his legs. This is effected by fastening in his mouth a steel machine termed a Bit, attached to a leather strap termed the Rein. The rider holds the rein in his hands, and may, if he can pull it with sufficient strength, keep the horse's head by main force in such a position that he cannot extend his neck. And if you can do this, whether by forcibly drawing down the horse's nose to his chest or by compelling him to raise it into the air, there can be no doubt that you will effectually prevent any ordinary horse from either walking, trotting, or galloping.

This, it is quite clear, is physically impossible. The neck of the smallest pony is far stronger than the arms of the strongest man, even if assisted by the weight of his shoulders. 
The strongest man will therefore fail in restraining by main force the action of his horse. It is true, no doubt, that the rider has certain odds in his favour. He can pull at the rein with all his strength; whereas the horse, if he pulls very hard at the bit, is likely to suffer pain from its pressure. The inexperienced horseman may therefore flatter himself that he will be able to control his horse by main force, not because the horse is physically unable to overpower him, but because he will be afraid of hurting himself in making the attempt. This, however, will be found a very dangerous mistake.

There is no truth whatever in the common superstition, that the mouths of some horses are naturally light, and those of others naturally hard. The mouths of all horses are tender to the bit, so long as its interior part presses upon the bars or gums, and its exterior part upon the beard or chin. The mouths of all horses are callous to the bit, when its interior part presses upon the corners of the mouth, and its exterior part upon the bones of the jaw. Every horse can therefore defy the pressure of the bit, so long as he can keep it in 
the latter position. By a hard-mouthed horse is consequently meant a horse which, either from natural make or from long habit, finds it easy to do this; and by a light-mouthed horse, a horse which finds it difficult or impossible.

Now it is obvious that, the more a horse draws in his nose towards his chest, the more directly the bit will press across his bars, and that, the more he thrusts out or throws up his nose, the more the bit will slip up towards the corners of his mouth. In other words, the horse's mouth will become sensitive or callous to the bit in proportion as he withdraws or protrudes his nose. A horse which always carries his neck curved and his head vertical will therefore be always light in hand; and a horse which can contrive always to carry his neck stiff and his head horizontal may defy any horseman in the world to regulate his pace or control his direction.

We may, however, be thankful that there is no such horse as this in existence. I have already said that no horse can execute any pace without stretching and relaxing his neck with the action of his legs. From this it is 
clear that no horse can execute any pace without becoming, at momentary intervals, comparatively sensitive to the bit. And therefore a horseman who knows how to take advantage of this, by yielding his hands when the horse extends himself so that he is able to resist the bit, and by pulling the rein when the horse bends or contracts himself so that he becomes sensitive to the bit, is able to regulate the paces of any horse in the world. The practice of this invaluable knack is commonly known as Giving and Taking.

The whole equestrian art may be said to consist in these two simple words. The horseman whose delicate tact enables him never to ri.k a pull which the horse is prepared to resist, and never to miss a pull which the horse is unprepared to resist, is absolutely perfect. His horse can make no movement which he will not foresee, and therefore none which he cannot if necessary baffle. Such perfection of handling as this cannot always be learnt, and is far from necessary; but no horseman who regards his own safety or comfort ought to be satisfied until he has acquired a certain degree of it. We have now to con- 
sider how this can be most effectually and most expeditiously done.

I. Riding on the Snaffle.-A plain Snaffle is a bit consisting simply of a single cylindrical bar, jointed in the centre and secured across the horse's mouth. When the snaffle rein is pulled, the bit presses the horse's bars if his head is in its natural place, and the corners of his mouth if his nose is thrown up or thrust out. The natural position of an ordinary horse, having a plain snaffle in his mouth, is with his neck nearly straight at an angle of about forty-five degrees above the horizon, and his head at a right angle to his neck. The plain snaffle, if judiciously used, is quite sufficient to control the horse's direction and to regulate his pace; but it has no power to bend or collect him into the attitude which makes his rider most completely master of his movements. The latter operation of the hand must therefore be discussed at a future opportunity.

Bégin by putting a plain snaffle on your horse, and adjust your bridle before you let him move. Place yourself with the upper arms

D 2 
vertical, the fore-arms parallel to each other, and the hands at the height of the elbows. Hold the rein in the full grasp of both hands, at such a length that you can just feel the pressure of the horse's mouth upon the bit; and secure it from slipping by your thumbs. Take particular care that your shoulders, elbows and wrists are perfectly supple, and prepared to play loosely with every movement of the horse's head. Let the rest of your body remain in its ordinary position.

Now let your horse move forward at a steady walk. You will find that the moment he begins to advance his neck begins to stretch and contract with every step he makes. Give your whole attention to the effect of this movement upon your arms. Keep them so loose and easy that they yield to every stretch of the horse's neck, but at the same time let them draw lightly towards you whenever the opposition of his mouth gives way. Endeavour in this manner to preserve one gentle and uniform feeling of the horse's bars, neither allowing the rein to tighten when he extends himself nor to slacken when he contracts himself. Avoid any attempt to alter 
his pace or his direction, and carefully keep the play of your waist and that of your arms independent of each other.

When you can feel your horse's mouth quite smoothly at a walk, you may begin to regulate his pace. For this purpose you must gently increase the pressure of your hands when his mouth gives way, and gently diminish their yielding motion when it resists. Do this at first with great caution and very lightly, for fear you should get into the habit of attempting to check him by a dead pull. Persevere in thus taking at every step a little more than you give, until the horse comes to a halt. By degrees, as the knack becomes more familiar to you, you may increase the power of your alternate pulls, until you can bring your horse in two or three paces from a fast walk to a full stop.

You may now proceed to the same practice at a trot and a gallop. Begin by starting your horse at a steady pace, and give all your attention to feeling his mouth without attempting to check or guide him. If he is disposed to press forward, let your assistant run beside you and regulate his pace. As 
soon as you have got him comfortably in hand, begin to shorten his action by pulling smoothly and steadily when his neck relaxes; and continue to do so until he drops into a walk if trotting, or into a trot if galloping. Be careful never to stiffen your arms so that they become insensible to the resistance of the horse's mouth, and never to assist them by the weight of your shoulders.

When you know how to regulate your horse's paces, you may begin to practise changing his direction. In order to do this smartly and suddenly, you must have command of his hind quarters; and you cannot have full command of his hind quarters until you have learnt how to use your legs. But the use of the bridle alone is sufficient to make him gradually swerve or circle to either hand. For this purpose you have only to incline your body and hands in the direction to which you wish him to turn; maintaining the feeling of his mouth with both hands, but strengthening the pull of the inward hand. The pressure of the inward rein on the bit, and that of the outward rein on the neck, will be sufficient to make a well broken horse 
turn correctly, provided the turn is not so sudden as to require his hind quarters perceptibly to depart from the line of his shoulders.

When you can ride, halt and turn your horse easily with both hands, you will have little difficulty in doing so with one. Your only embarrassment will be the necessity of making up for the diminished play of the bridle hand by occasionally shortening and lengthening the rein, and the consequent temptation to avoid this necessity by thrusting forward the bridle arm and shoulder instead of carrying the body square. You will avoid it by getting into the habit of letting the reins pass loosely between the fingers of the bridle hand, and grasping them next your body with the fingers and thumb of the other. Both hands will thus naturally place themselves in front of your waist; and when one is dropped or removed, the other will instinctively retain its central position.

There are two causes which usually prevent the acquisition of a perfect bridle hand. The first is the unsteadiness of the rider's seat. The second is the habit of pulling at the reins 
by the weight of the bust instead of by the play of the arms. No man can give and take as he ought while he is being jolted about in his saddle, nor yet while his body is hanging upon, and supported by, his bridle. The former difficulty you can only overcome by patiently working yourself into a perfectly smooth and steady seat before you attempt to manage your bridle. The latter you must avoid by carefully keeping your arms detached from your body, and allowing them to play freely in the air with the pull and yield of your horse's mouth.

Do not be deluded by the indiscriminate praise usually bestowed upon a light bridle hand. A light hand is a good thing, but only when it is effective as well as light. The first merit of the hand is to command the horse; the second is to do so without unnecessarily annoying him. Nor ought the hand to be light when the horse resists it. A hand which is always light will be as ineffective as a hand which is always heavy. The hand of a horseman should resemble the tempert of a commander-pleasant while obeyed, formidable if disobeyed. Nobody cares for the man who 
always smiles, any more than for the man who always scolds.

2. Riding on the Curb.-An ordinary Curb is a bit consisting of a curved bar or mouthpiece fastened across the horse's mouth, and having a Cheek, or cross-bar, at each end. To the lower ends of the cheeks are fastened the ends of the rein, and their upper ends are connected by a chain which passes under the horse's chin. When the curb rein is pulled, the upper ends of the cheeks rise and tighten the curb chain across the horse's chin, and at the same time the mouth-piece turns and presses its Port or curvature against the roof of his mouth. The natural position of a well made or well broken horse, when properly ridden on the curb, is with his neck arched and his head vertical; and the curb is therefore useful, not only to regulate the horse's pace, but also to place him in a graceful and manageable attitude.

Begin to practise riding upon the curb without using the snaffle at all. Mount your horse, and keep him at a halt until you have learnt the proper feeling of his mouth. Take up 
the rein with the fingers and thumb of the right hand, and draw it through the fingers of the left hand until you meet with a gentle resistance. If the horse has a good mouth, he will gradually arch his neck until his head drops into a vertical position, and champ or play with the mouth-piece of the bit. Let slip the rein when he yields in this manner to the hand, and allow him to extend his neck. Then proceed to repeat the same practice, until you can catch him upon the curb and bring home his head with a quick and easy touch, and without any uncertainty or delay.

When you have mastered this knack, put your horse into a walk. If he has a good mouth, he will move off without endeavouring to extend his neck or thrust forward his nose. As he steps along, you will become conscious no longer of a steady though intermittent pressure upon the mouth-piece, but of an elastic play or vibration of the cheeks, which increases or diminishes with the movement of his crest, but never wholly ceases. Carefully watch the ebb and flow of this soft and almost imperceptible sensation; and endeavour to let your hand give and take, so as 
to keep it as nearly as possible uniform. You will soon find that you can detect both its absence and its increase, although you do not seem to feel its presence; and this curious faculty will be your guide in maintaining it.

If your horse is a good steady goer, who does not require much assistance from the legs, you may now ride him at a short or collected trot or canter. Endeavour to maintain the elastic play of the bit, and to keep his neck arched and his head home. If he extends his neck and protrudes his nose, try to check him by feeling the rein as if you were very gradually pulling him up, at the same time urging him forward, or making your attendant do so, by a touch of the whip. You will soon become aware of the great pleasure which a light mouthed and high couraged horse, skilfully. kept in hand with the curb, bestows both upon the rider and upon the spectator.

No ordinary horse should ever be ridden, except for the purpose of instructing his rider, otherwise than in a curb and snaffle at once. He cannot be compelled to put forth his full powers in either of these bridles singly. If you ride him in a single curb, or as it is com- 
monly called a hard-and-sharp, you cannot leap him over a fence, or even extend him at a full trot or gallop, without letting go his head. If you ride him in a single snaffle, you cannot bend or collect him so as to show off his action and make him handy in turning or circling. You must therefore, in order to be fully master of your horse, learn to combine the use of the curb and snaffle, or bit and bridoon, by riding him in a double bridle comprising both.

You will find no great difficulty in this. Take the two reins in both hands, the little fingers dividing the bit from the bridoon rein, and hold them at equal lengths. You will immediately feel a steady pressure upon the bridoon; but you will also feel that, if you raise your hands or if the horse thrusts out his nose, the bit forthwith comes into play. You thus gain the advantage of holding your horse firmly by the head however fast he may go, while you keep in reserve a mode of handling which will effectually prevent him from raking or boring against his bridle. As soon as you are familiar with the use of the double bridle in both hands, take it in one, and divide 
the bit from the bridoon reins by your fingers, keeping all fast by the thumb.

No horse suppled according to M. Baucher's system requires any bit except a plain snaffle and an ordinary curb; and I believe that there is scarcely any horse which may not be suppled according to M. Baucher's system. But this is not generally known; and you will often find, when you mount a hot or hardmouthed horse, that he has been equipped for your especial convenience with some engine of torture which is expected to make him more easily controllable. In such cases you will always, if you take my advice and can find an opportunity, procure the exchange of the Chifney or Segundo for a simple bit and bridoon. But if this is impossible, a light and elastic hand will do wonders in reconciling the poo animal to his unnecessary punishment.

I give you no special rules for leaping. If you are cool enough not to change or stiffen your attitude as your horse rises, you will naturally sit steady in your saddle; and if you sit steady in your saddle, you will naturally handle your horse as you ought. A flying leap is nothing more than a stride in the horse's 
gallop of extraordinary height and width; and a standing leap is nothing more than the commencement of his gallop with such a stride. If therefore you know how to give and take properly, and if the unusual effort which the horse is making has not disturbed your seat so as to disable you from giving and taking properly, you have no further difficulty to overcome. 


\section{CHAPTER III.}

THE LEGS.

The MAN who has acquired a perfect seat and a perfect hand is in England considered as a perfect horseman. We all know that there is some difficulty, and therefore some merit, in sitting a horse firmly and in handling him skilfully. But few of us seem to be aware that any science is required to make him exert himself according to his rider's pleasure, or even that a horse, if made to exert himself sufficiently and kept well in hand, can possibly be otherwise than completely under his rider's command. The consequence is that the scientific use of the legs or spurs is entirely neglected by most English horsemen.

It is easy to account for this omission. The ordinary English horseman is accustomed only to work his horse upon a single line. Whether he rides upon the road, upon the race-course, or across country, he is quite satisfied so long 
as his horse goes forward freely and yields to the bit readily. The dexterous manœuvres of the manége he does not find necessary; and therefore he despises them as mere ridingschool tricks, unworthy the attention of a practical sportsman. That their successful study would enable him to ride an ill-made or ill-broken horse with greater pleasure and safety than he can do at present, he probably does not know and would not believe.

It must not, however, be supposed that the English horseman sustains no positive inconvenience from this neglect. It is true that he only requires his horse to work straight forwards; and it is also true that a high couraged horse, so long as he works straight forwards, requires nothing but a good hand to make him go as he ought. But suppose that the rider requires his horse to work straight forwards, and that the horse is resolved to swerve aside. Excellent judges have long ago remarked that the same man who can regulate a free going horse in his gallop and pilot him over his fences with the precision of clockwork, is often quite at a loss when mounted on a sulky or timid animal which refuses to leap; and a certain 


\section{The Legs.}

degree of the same awkwardness may often be remarked on the road, when it becomes necessary to open a gate or to pass an object of which the horse is afraid.

This is very readily explained. An active horse can, as every horseman knows, change the direction in which he is going, without either slackening his pace or turning his head, by simply carrying his hind quarters to the right or left, and working sideways instead of straight forwards. An active horșe can therefore proceed in a direction contrary to his rider's will, without resisting his rider's hand. In other words, no rider has complete command of his horse until he has learnt to regulate the movements of his hind quarters as well as to handle his mouth. This can only be done by the judicious use of the legs or spurs.

A well-broken horse whose flank is struck or pressed will instinctively endeavour to withdraw himself from the contact. This is the obvious principle upon which the horse's hind quarters are controlled by the rider's legs. When the rider closes both legs to his horse's flanks, the horse will instinctively move forward 
or increase his pace. When the rider closes one leg the horse will instinctively shift his croup or step aside in the opposite direction if he was previously standing still, and will instinctively traverse or sidle in the opposite direction if he was previously advancing. The use of the legs, in short, depends upon this simple truth - that whenever you touch your horse's flanks, he will promptly throw his weight the other way.

It must however be remembered, that the use of the legs will be of no advantage whatever unless it is combined with that of the bridle. The horseman who drives his horse forward without knowing how to keep him in hand is getting up steam without having provided a rudder, and will find that, the more the animal is roused to exert himself, the more headstrong and unmanageable he becomes. The horse is excited by the pressure of the legs to throw his weight forward, and the inelastic hand of the rider is overpowered by the sudden impulse which it is thus required to support. The consequence is that the horse begins to bore heavily upon his shoulders, and unless pulled short up will probably attempt to run away. 
But the case is very different when the horseman knows how to catch and balance in his hands the weight which he has thrown forward by means of his legs. The horse may spring forcibly from his hind-quarters, but the bent position of his neck keeps his mouth sensitive, and disables him from carrying the impulse of his spring so far as to increase his pressure upon the bit. The rider has, therefore, obtained the equilibrium which is the object of every skilful horseman. The horse, as it is technically expressed, is before the legs and behind the hands. In other words, he is ready to spring forwards or sideways at the slightest touch of the leg, and yet is restrainable from doing so by the slightest feeling of the hand.

In my instructions how to acquire the proper use of the legs or spurs, I shall of course take for granted that you are mounted upon a horse sufficiently well broken to obey with perfect docility the ordinary indications of a skilful horseman. In England this sort of animal is not always easy to procure, but with a little patience you will probably succeed in getting one quite good enough for your E 2 
purpose. What is termed a highly managed charger is altogether unnecessary; because, however far you may wish to carry your own education, you will find it easy, when you have once acquired a certain degree of tact, to push forward that of your horse at the same time.

I. Working in Line.-Begin by acquiring the knack of moving your legs freely without disturbing your seat or hand. Do not resemble that unskilful cavalier recorded in Henry IV., who 'gave his able horse the head, and bending forward struck his armed heels into the panting sides of the poor jade.' Shakespeare no doubt drew from nature; but we know that nature sometimes turns out very indifferent horsemen. What do you suppose would have happened if the poor jade, instead of answering the spur like an honest horse, had set up his back and given a resolute plunge? The unwary messenger would have been thrown clean out of his saddle, and the king would have had to wait another post for news of the battle of Shrewsbury.

Commence your practice without spurs. 
Fix yourself in your seat, bring the horse's head home with the curb; and then, keeping him at a halt, proceed to close your legs and heels to his flanks. Steadily maintain the pressure notwithstanding his fidgeting or shifting to avoid it, trying not to let him move forward, and taking care not to stiffen your body or relax the grasp of your thighs. When you can do this with perfect ease, go on to practise it at a walk, trot, and canter. You will soon find that the constrained position of the leg, though certainly no assistance to the gripe of the thigh and knee, need not be allowed to interfere with it.

Next put on a pair of ordinary road-riding spurs, with blunt rowels. Seat yourself and take hold of your horse as before, move him forward at a walk, and then close your legs steadily and touch him lightly with the spurs. If he is a good-tempered, high-couraged horse (and Ineed not say that for this lesson you must not choose a dull or a restive one), he will sink his croup and try to spring forward. Carefully keep him bent with the curb, so that he cannot get a pull at your hand. If you do this skilfully, the result of the impulse will be 
merely to raise his forehand and bring his hind legs well under him ; and you must persevere in the present practice, though without using the spurs if you find the pressure of your legs sufficient, until you succeed in producing this effect and no other.

When you have fairly got your horse between your hands and legs at a fast walk, proceed to shorten his pace until, without letting him escape from his equilibrium, you have brought him to a full halt. Then drop your hands and legs, and permit the horse to stretch his neck and stand at his ease; and then, gently drawing the rein and closing the legs, endeavour to bring him again into balance without permitting him to shift his ground. This is a task of considerable delicacy, and you will require some practice before you can do it quickly and completely; but your success will be rewarded by a consciousness of perfect command over your horse such as you never felt before.

Reining back must be your next lesson. Get your horse collected and light in hand at a halt; and then, by alternately relaxing your hands and legs, induce him to throw his 
weight alternately upon the forehand and the haunches, without stepping forward or backward. You will soon, if you are skilful in thus soliciting him to change his balance, become conscious of a gentle but perceptible oscillation of his body upon his legs. Catch your opportunity when the reflux of his weight from the fore to the hind legs is just beginning, maintain the pressure of the hands and forbear to renew that of the legs. The inevitable consequence will be that he will step backwards at a steady walk.

When you have got your horse well collected at a walk and a halt, you will probably find little difficulty in keeping him so at a trot and a canter. Indeed, if the contrary should happen, the fault is more likely to be his than yours; and the remedy is therefore no part of our present subject. If, on the other hand, you feel him when in quick motion eager to spring from the spur, yet reluctant to throw his weight upon the bit, the natural power of the animal will be the only limit to your command over him. By judiciously timing your indications, you may make him bound and curvet, caper and caracole, 
so as to realize, if you think it worth while to do so, the equestrian marvels of chivalrous romance.

You will easily perceive that the true difficulty of your present practice consists, not in the proper use of the legs themselves, but in the additional difficulty which their use will throw upon the hands. The office of the two is different but similar. As the hands are to yield when the horse's mouth resists, and to pull when it gives way, so the legs are to close when the horse's weight falls backward, and to relax when it flows forward; and therefore a perfect horseman will seldom or never use his hands and his legs precisely together. But the difference between the two indications is this ; that the horse's flanks are comparatively callous, and that his mouth is highly sensitive. The use of the legs will therefore, if well timed, be always tolerably correct; whereas that of the hands requires in addition the most careful elasticity of touch.

2. Working sideways. - When you have got your horse perfectly collected and light in hand while working in a straight line, you 
will have no difficulty in making him work correctly with his fore and hind quarters upon distinct lines. Begin, as before, at a halt. Bring the horse's head home; and close one leg to his flank behind the girths, restraining him by the opposite rein from shifting his forehand. He will immediately shift his croup in the opposite direction, and if the pressure is continued will circle his hind completely round his fore legs. Next turn his head to one side by the rein, and restrain him by the opposite leg from shifting his croup, which will cause him to shift his forehand without moving his hind legs until he circles upon the latter.

With a perfectly docile and well-broken horse, these are very simple manœuvres. But you must, in performing them, be upon your guard against any irregular movement which he might make if impatient or reluctant. In circling on the forehand, be ready to stop him by carrying the hands in the opposite direction if he begins to change ground with his fore legs. In circling on the haunches, be equally ready to arrest the movement of his hind legs by the application of your opposite 
leg. And in all circles at the halt let your hands carefully restrain him from stepping forward, while the instantaneous closing of both legs must prevent hirn from reining back.

When you can circle or pirouette your horse quickly and smartly, yet with perfect accuracy, you may try the passage or side step. For this purpose you have only to get your horse well in hand at a halt, and then, alternately turning his head aside by the rein and pressing his opposite flank with the leg, induce him to shift alternately his fore and hind legs in the opposite direction. The outer rein is to assist the leg by pressing the neck so as to lead off the forehand, and the inner leg is to stop the croup if it traverses too rapidly. The horse will soon comprehend the movement which he is required to execute, and will, under the simple pressure of the outward leg assisted by the feeling of the inward rein, begin to step sideways by crossing his fore and hind legs simultaneously and not alternately.

You may now, if you choose to amuse yourself by doing so, practise at a trot the same movements which you have learned to 


\section{The Legs.}

execute at a walk. First get your horse well collected at a steady advancing trot; and then, by delicately increasing the pressure of your hands, without ceasing that of your legs, gradually shorten his pace until he correctly executes at a halt the motions of a full trot. This exercise is termed Piaffing. It is one of great difficulty; and its successful performance, even by the best broken horse, requires unusual tact and skill in the rider. When you can once make your horse piaff you may, by persevering upon the same principles, induce him to rein backwards, or to passage sideways, at a full trot without changing his action.

Until you are tolerably perfect in circling and passaging at the walk and trot, or at all events at the walk, you must not attempt to work sideways at the canter or gallop. The reason of this is obvious. A horse advancing at the walk or trot works his legs diagonally and moves square to the front, so that he can swerve with equal readiness to either hand. But a horse advancing at the canter or gallop moves by a succession of strides or springs, in each of which his fore and hind legs on one side lead, and are followed by those on the 
other; and whoever watches his action will perceive that he cannot, without imminent risk of falling, swerve towards the hand on which his legs are not leading. You cannot, therefore, safely circle or passage a horse at the canter, until you have learned to make him canter with whichever leg you please.

In order to put a horse out of a walk or trot into a canter or gallop, you have only to collect him by applying your legs, without allowing him to increase his pace, until you feel him raising his forehand and beginning to prance, and then gradually to let him out straight. In this case he will, of course, lead with whichever leg he happens to prefer. But if you wish him to lead with the right (or left) leg rather than the other, you must, as soon as you feel him prepared to strike a canter, carry his croup to the right (or left) by increasing the pressure of the left (or right) leg, and at the same time lead him off by feeling the right (or left) rein. And when you can do this with ease and certainty, a little additional practice will enable you to make him change his leg at your pleasure while actually on the canter. 
You will occasionally find yourself mounted upon an otherwise well broken horse which, either from natural make or from long habit, is very reluctant to strike a canter. In such cases, you must have recourse to what is termed lifting him - a manœuvre perpetually practised by all experienced horsemen, but never, I believe, described or even noticed by writers upon horsemanship. It is performed by smoothly but vigorously giving and taking the snaffle, while the horse continues to trot, with the movement which your hands would naturally adopt if he were cantering. Do this steadily and perseveringly, neither jerking the horse's mouth so as to make him throw up his head nor pulling at it so as to shorten his pace, and he will very soon be unable to prevent himself from falling into the pace which you require.

A horse is said to canter Disunited, when he leads with opposite legs before and behind. This way of going is both uneasy and unsafe, and must be immediately corrected. If you wish him to change with his fore legs, throw the weight of his forehand upon the fore leg which is leading, by carrying your hands to 
that side. If you wish him to change with his hind leg, throw the weight of his croup upon the hind leg which is leading by applying the cpposite leg. Both changes are easy and certain, provided the horse remains light in hand and collected, or can be got so before the attempt is made. 


\section{CHAPTER IV.}

THE NERVES.

WE will now suppose that you are, physically speaking, a perfect horseman. In other words, you can ride your horse, so long as he is willing to obey you, precisely as he ought to be ridden. Even so you are, physically speaking, a consummate swordsman when you can defend yourself so as never to be hit with the foils. But as the champion of the fencing-school sometimes forgets his science when first he sees the point of a rapier presented at his body, so the model of the manége is sometimes startled into awkwardness when first he feels beneath him the plunge and rush of an angry or frightened thoroughbred. In both cases, we know, the novice has within him the means required for safety; but in neither is he sure of retaining his presence of mind so as to be able to use them.

If you take my advice, you will not leave 
this important question to be answered by the event. You can, if you will use the necessary means, gradually familiarize yourself with the action of an unruly horse, until you are quite secure upon the back of the great majority. But your training for this purpose must be moral, not physical. You already know how to communicate your wishes to your horse, and how to sit upon his back while he obeys them. You must now learn how to make him obey them, and how to sit upon his back while he is attempting to disobey them. The skill which you have already acquired will be amply sufficient to effect this, provided you can secure your command of it by one important acquisition. That acquisition is the quality which we term Nerve.

By Nerve is understood the faculty of not overrating danger. It is therefore a quality quite distinct from courage, which is the faculty of disregarding danger. The courage which enables us to face real danger can only be supplied, when it is naturally absent, by a strong will or a high sense of duty. But the nerve which enables us not to shrink from imaginary danger will come of itself, so soon 
as familiarity with the circumstances has taught us that the danger is imaginary. Now there can be no doubt that the danger which a skilful horseman incurs by riding a restive horse is, except in very extraordinary cases, almost entirely imaginary ; and a skilful horseman will therefore; as a general rule, acquire nerve by becoming accustomed to ride restive horses.

Still you must remember that a general rule may easily be far from an invariable one. The force which a restive horse can exert for the purpose of overpowering his rider is sometimes very great. If you have presence of mind enough to sit and manage him as coolly as in his ordinary paces, you will baffle his efforts with ease. But if you allow yourself to be startled out of your position on his back and your command of his mouth, you may easily be unseated or run away with. The discouragement naturally caused by such an accident will, of course, greatly retard your progress in horsemanship. You must, therefore, in order to acquire with quickness and certainty the art of riding restive horses, commence your practice under circumstances 
which are likely to protect you from serious risk in case of mismanagement.

I. Sitting a Restive Horse.-In order to acquire a firm seat upon a restive horse, you must first of all put out of your head the precepts of those teachers who advise you to assume particular attitudes in particular emergencies. A moment's reflection will show that, whether wise or foolish in themselves, they cannot be of the slightest use to a novice. You are told, for example, to lean backwards when your horse kicks. Does this mean that you are to lean backwards when you feel him kick, or that you are to lean backwards when he is going to kick? In the former case you are told to do what you will find physically impossible; in the latter you are supposed to know what you have no means of knowing. Your only present chance of success is to select a position in which you are likely to be secure, whatever your horse may do, without any conscious change of attitude.

There are only two ways in which a restive horse can unseat his rider. He may kick and plunge so as to throw you from the saddle 
by main force, or he may start and shy so as to twist from under you. But, so long as you retain your proper position on his back, he can do neither; because, in this case, your weight will rest upon a part of his back which he is physically unable to move with sufficient violence to inflict upon you any considerable shock, and your body will be poised and secured in an attitude which will prevent your weight from being displaced. You have, therefore, in order to sit a restive horse with security, two things to learn : first, the nerve to retain your proper position without constraint while he is struggling to unseat you; and secondly, the presence of mind to catch your proper position whenever he tries to surprise you.

You cannot begin better than by practising the standing jump, without using the reins. Lay a leaping-bar on the ground, and let your assistant lead your horse across it. If he is a clever fencer, he will rise and hop over it with a movement pretty closely resembling the short angry plunge of a horse beginning to try his rider's seat. Keep your gripe steady, your shoulders well back and your waist supple, 
and you will sit him with perfect ease; stiffen or round your spine, and you will feel yourself more or less shaken in your saddle. Proceed by degrees to raise the bar, until it is as high as the horse will consent to jump without a rush; and then place another bar at the distance of seven or eight feet beyond the first. You will soon find that, if you are but cool enough not to alter your position, you are perfectly secure in your seat.

When you can sit a double jump of tolerable height, you are not likely to be displaced, if on your guard, by any succession of kicks or plunges which an ordinary horse is able to execute. But you are still liable to be taken by surprise. It is one thing to retain a position which you have deliberately assumed, and quite another to catch a particular position instinctively, when startled by the sudden rebellion of a vicious horse. This all vicious horses know perfectly well; and therefore they seldom assail their rider's seat without first trying to disturb his self-possession by a half-rear, a side start, or some other mancuvre of the same kind. You will consequently never be secure upon such a horse, until you have 
learnt to trust the strength of your proper position on horseback with such implicit faith, that you throw yourself into it when startled as instinctively as a timid horseman catches hold of the mane or the saddle.

There will be no great difficulty in acquiring this confidence. First, fix yourself in your seat; and let your assistant lunge your horse at a walk, making him spring forward unexpectedly at intervals by using the whip. When this ceases to startle you, sit loosely and repeat the same practice, catching your gripe as you feel the horse commence his spring. Then let your assistant endeavour to make the horse stop short, twist round, or spring aside, first when at a walk, and then when at a trot or canter. There will be no occasion to carry this part of your education so far as to injure the animal's temper. Be satisfied when you find that the sudden interruption of his regular action startles you into your proper attitude and not out of it.

The instinctive feeling which you are to aim at acquiring may be very simply described. In your proper position, the gripe of your legs is sufficient to prevent you from falling back- 
ward, the weight of your bust to prevent you from falling forward, and the suppleness of your waist to prevent you from falling sideways. These plain truths you must thoroughly realize. Learn to hollow your waist and throw back your bust without a moment's hesitation whenever your horse makes an irregular movement, in the perfect confidence that your legs will catch the saddle in time to prevent you from rolling over his quarters. Once acquire this instinct, and you may defy the various wily manœuvres by which, like a wrestler playing to get his lock, a vicious horse will endeavour to tempt you into a position which he feels will enable him to kick you over his head.

Always bear in mind, during this part of your progress, that there is one important difference between a start and a plunge. If a shying horse unseats you, it is by mere accident. He only wishes to avoid going in a particular direction. He knows, as I have already explained, that your hands cannot prevent him from doing this; and therefore he does not attempt to alter his bearing upon the bridle. But a horse which plunges 
does so with the intention of unseating you. He knows that he has a much better chance of succeeding if he can prevent you from feeling his mouth; and he therefore almost always commences his rebellion by throwing his head up and down. You must, consequently, when practising to sit a plunging horse, invariably do so with a slack rein.

When you begin to test your nerve by riding really restive horses, you will act wisely by mounting the first two or three in the lunge. You cannot leave such a horse's head at liberty without risking a serious accident, and you cannot fairly try your power of sitting him without slackening your reins. You must therefore, in order to make the experiment at once safe and effectual, get him kept in hand by another person; and you will do well to take care that this person is an experienced horsebreaker, and if possible that he is acquainted with the horse which you are to mount. Thus prepared, and keeping in mind your former practice, you may ride nineteen restive horses out of twenty with very little real danger. 
2. Managing a Restive Horse.-Until you are quite sure that you can sit a horse which rebels, do not attempt to prevent his rebellion. By doing so you will probably fail in both your objects. The necessity of using your hands and legs will make you forget to keep your proper position in the saddle, and the consequent unsteadiness of your seat will disable you from properly using your hands and legs. The necessity of promptly using your hands is moreover likely to betray you, if you are not sure of your seat, into the habit of unconsciously holding on by the bridle-a trick which, besides being necessarily fatal to anything like proper management of the mouth, is very likely to get you unseated if your horse should suddenly throw up his head.

But we will now suppose that you are quite firm and easy when assailed by the ordinary start or plunge of an ordinary horse. In this case it is time to consider how you can prevent your horse from starting and plunging, or how, if taken by surprise when riding carelessly, you can regain your command over him. In order to answer this question you must first ascertain whether your horse is a 
well broken one or not; that is to say, whether he has or has not been successfully taught to arch his neck and gather his haunches under him when collected by the hands and legs of his rider. If so, you will in the great majority of cases find it perfectly easy to subdue him. Strike him with the spurs and take a pull at his head, and he will come together at once.

Of course I do not mean that a well educated horse will never rebel. Well educated horses, like well educated men, can make fools of themselves if they choose. He may rear, run back, stand still, or kick and plunge; and if you try to ride him over a cliff, or into a furnace, he will probably do so. But in this case his rebellion will be deliberate and resolute; and every man who has felt the extraordinary moral authority possessed by a good horseman over his horse, knows how much it takes to make a well ridden horse deliberately and resolutely rebel. It is by petty tricks and subterfuges that an ordinary horse tries to baffle his rider; and it is scarcely too much to say that of such manœuvres a properly educated horse becomes absolutely incapable.

You will thus perceive that obedience to 
the leg is the keystone of the horse's education. Without it, the lightest mouth and the finest hand are of no more avail than a good rudder and a skilful helmsman when the boat has not steerage way. What does a horse care for your perfect command of his head and neck, so long as he feels that, by running backwards or sideways, he can go where he pleases in spite of you? He knows, if you do not, that it is the leg which must place him in that position which alone will allow the hand to exercise any efficient control over his movements.

Nor is this all. A horse which does not obey the leg cannot have a permanently light mouth. It is impossible to prevent such a horse from occasionally, for a short distance, running away with you. Once permit him to draw back from the bit, and he can if he pleases come upon it with a rush which will for the moment carry all opposition before it. It is therefore absolutely necessary, in riding fiery and impetuous horses, to lose no time in getting them well in hand by the use of the legs or spurs. Your only chance of keeping such a horse in perfect command is to detect 
and counteract his first attempts at insubordination, and this you cannot do if you allow him to go behind his bridle.

Moreover, a horse which does not readily obey the leg can never be ridden at speed with comfort or safety. He cannot extend himself at full gallop without throwing his weight forward, and he cannot throw his weight forward without becoming to a certain extent unmanageable by the hand. A good horseman whose horse has succeeded in bolting will therefore, before he takes a pull at the bridle, always endeavour to collect the pace by the use of the legs or spurs. If he succeeds, the horse will come together and yield to the hand at once. If he fails, it will cost him some time and exertion to pull up. We all know that race-horses, which are educated for speed alone, perpetually contrive to run away with the best jockeys in England.

If you find yourself mounted upon a fiery and violent horse which has not been properly broken, your only resource will be in the delicacy of your bridle hand. Here, I freely acknowledge, science can do but little to assist you. Science can teach you how to ride a 
horse which has a good mouth, and how to give him a good mouth if he has a bad one; but how to make the best of a bad mouth while it continues bad, is a question which only instinctive tact or long experience can decide, because it requires a different answer in almost every different case. If, however, you are quite steady in your seat, and know how to give and take and how to shorten and let slip your reins, you will not be long in acquiring dexterity enough to control any ordinary runaway.

But suppose your horse has fairly bolted, and that you find your legs or spurs unable to collect him. He cannot do this so long as the bit rests across the bars of his mouth; and there is only one expedient by which a runaway horse can permanently avoid the pressure of the bit upon his bars. He cannot, or rather he dares not, continue to gallop with his nose thrown up, or even with his head horizontal. But he can gallop pretty safely, though not perhaps very easily, with his head and neck boring down between his fore legs; and so long as he does this you cannot get a pull at him, because whenever 
you attempt it the bit will slip up and rest across the corners of his mouth. In this case your only resource will be to saw the snaffle, by giving alternate pulls at each rein. Do this smoothly and quietly, and you will seldom find it fail in bringing the most headstrong fugitive to a halt in a very few strides. 


\section{CHAPTER V.}

BREAKING THE HORSE.

You are now, if you have diligently and successfully practised the precepts already laid down for your guidance, completely master of any well educated horse. But few horses -certainly very few English horses-can be called thoroughly well educated. The chances therefore are, that whatever horse you may procure for your own riding will require some additional education. And the question now remains, in what manner this education can best be supplied.

The complete education of a saddle horse consists of two distinct branches. He must be made willing to obey his rider, and he must be taught to understand his rider. The former of these two branches of education is termed Breaking the horse, and the latter Suppling him. They are, as every clearheaded man will immediately perceive, entirely 
distinct in their object, and ought to be entirely distinct in their method of practice; but they have been long confounded together by pedantic and unscientific equestrians. The demonstration of this almost universal mistake is one of M. Baucher's many eminent merits.

The mere breaking of a young horse is an exceedingly simple matter, and would be an exceedingly easy one if it were always entrusted to patient and gentle hands. A horse is completely broken as soon as he carries his rider, without resistance or reluctance, at a walk, trot and gallop. This he will readily do when he is once brought to understand that neither his rider, nor any of the new and strange objects to which his rider must necessarily introduce him, is going to do him any harm. And if he is treated with due kindness before breaking, and with due forbearance while being broken, he will very speedily acquire this conviction.

We all know that the breaking of a young horse consists of two steps, Lunging and Backing. He is first taught to advance steadily by being driven round and round in a lunge 
or long rope ; and he is then gradually induced to bear the saddle, to carry a rider upon his back, and to advance mounted as before. If all this is cautiously and skilfully done, it may be effected without arousing the horse's temper or provoking him to resistance; and he will then, in order to be completely broken, require nothing but to be led about the country by a steady and patient groom, until he ceases to take fright at the various moving objects which he is likely to encounter upon the road.

To do all this successfully does not require more judgment or dexterity than is usually possessed by an ordinary rough-rider. If therefore you have a colt to break, you may safely entrust him to any ordinary rough-rider in whose sobriety and good temper you have perfect confidence, or whose proceedings you have the opportunity of superintending in person. Your principal care must be to see that the colt is never roughly treated, and that he is never tired by being worked too much at a time. Avoid in particular the dangerous error of beginning to back him when he is wearied and disgusted by a long 


\section{Breaking the Horse.}

$8 \mathrm{I}$

drive in the lunge, instead of watching for a moment when he is just warm to his work, and in thorough good humour with it.

Do not, unless you are one of those adventurous persons who delight in risking life and limb, be tempted by your confidence in your own horsemanship to mount a newly-broken horse upon his first introduction to the world. $\mathrm{Be}$ assured that the quietest colt is very likely to bring the best rider into serious danger. That excellent judge, 'Harry Hieover,' has told us that the most vicious demon ever foaled is less desperately dangerous than a well-meaning horse fairly frightened out of his wits. This is easily explained. Remember that you can only restrain a horse from running away, because you can keep his head in a position which makes him afraid to run away; and what does a terrified maniac know of fear, except the particular fear which is driving him frantic? What was long ago said of assassins is no less true of horses: He who has ceased to care for his own life is always master of yours.

Before a newly-broken horse becomes ready for suppling, his docility will usually require 
some confirmation. Ride him regularly upon the road, suiting the amount of work to his strength and courage so as to train and practise without fatiguing him. Use nothing but a plain snaffle and a whip - the curb and spurs are to be introduced hereafter. Require him to execute no pace except a fast walk and a moderate trot, but insist that in both he shall always be fairly up to his bridle; in other words, keep him alive with the whip so that he requires perpetual holding with the snaffle. A very few weeks of this exercise will, if he is naturally good tempered and has been judiciously broken, make him a lively, free-going roadster.

In saying this, I of course take for granted that your horse instinctively understands what is meant by the use of the whip. This, however, is not always the case. A horse which is struck with a whip by a man on foot will naturally endeavour to escape a repetition of the blow by moving away from the assailant. But a horse which is struck by a man seated on his back has no obvious means of escape except by throwing his rider; and this he will very probably endeavour to do, unless he has 
been made to understand that the blow will not be repeated if he promptly moves in a particular direction.

M. Baucher has suggested a very easy and simple method of effecting this purpose. Stand by your horse's head, holding the bridle in one hand and the whip in the other, and tap him on the chest with the whip until he endeavours to escape you by stepping back. Hold him fast, follow him steadily, and continue to use the whip. When he finds that stepping back is useless, he will endeavour to spring forward. Immediately drop the whip, and show your satisfaction by caressing him. Repeat the lesson until he springs forward at the slightest touch or even movement of the whip, whether held by a person on foot or on his back. You cannot mount any horse with safety, which you are not sure of being able to drive forward at your pleasure.

There is one modification of M. Baucher's system which I would here venture to suggest. I am inclined to believe that a young horse will be sooner familiarized with the spurs, and will more readily learn to understand their meaning, if his introduction to them takes 
place while he is being snaffle-ridden at a smart pace, than if it is deferred ustil he is being suppled at a halt or a walk. Use them lightly; and be ready to explain their application, if he shows signs of fear or temper, by adding that of the whip. When he answers them kindly and promptly, without shrinking together or laying back his ears, it will be time to proceed with the second and more difficult part of his education. 


\section{CHAPTER VI.}

SUPPLING THE HORSE.

To talk of suppling a horse is of course, in the great majority of cases, a complete misnomer. Any tolerably strong and active horse is naturally able to exert, without the slightest difficulty, a much greater degree of muscular elasticity than his instructor is likely to require from him; and it is only the education of tolerably strong and active horses that we are now discussing. It is no doubt possible to fortify and improve by gymnastic training the natural powers of a weakly or mis-shapen horse; but the method of doing this forms no part of my present subject. The word suppleness must therefore, throughout the present chapter, be understood as simply meaning Intelligent Obedience.

No man who has ever mounted a horse requires to be told that, the more the animal exerts himself, the more difficult to manage he 
becomes, or in other words that the increase of his action tends to diminish his suppleness. The pull which would throw him on his haunches at a walk will merely shorten his stroke at a full trot, and will scarcely be felt at a gallop. This is a difficulty which has never yet been overcome. None of the established schools of horsemanship have been able to invent a method of educating the horse, which shall put him completely under. the command of his rider without confining or impairing the full exercise of his natural powers.

The English horseman, with characteristic though perhaps unconscious good sense, sticks to the preferable and wholly abandons the inferior alternative. He has no regular method of suppling his horse at all. Whatever lightness in hard an English horse may possess is in most cases entirely the result of natural good shape and good temper, assisted by habitual good riding. The consequence is that an English horse, though usually safe and often pleasant to ride, is very seldom so educated as completely to satisfy a scientific horseman, but that this deficiency is compen- 
sated by the unimpaired strength and courage which enable him to perform such wonderful feats in the field.

The Asiatic horseman chooses his course as logically, though perhaps less judiciously. $\mathrm{He}$ deliberately fetters the action of his horse in order to make him manageable. He never mounts without first securing the animal's head in a vertical, or almost vertical, position by means of a standing martingale. Thus manacled, and ridden by a dexterous horseman with sharp stirrups and bit, the colt can, after a very few days' practice, be forced to execute any manœuvre which his rider may require. But he is unable to leap a fence or to gallop at speed until released from his unnatural confinement; and if released he becomes, of course, as unmanageable as he ever was.

The horseman of continental Europe adopts a compromise, by which he expects to secure the combined advantages of these two methods, but which is usually found only to unite their inconveniences. He puts his horse through a long and painful course of school discipline, whose ordinary effect is permanently to cow the animal's spirit and cripple his paces. The 
consequence is that the French or German cavalry can rival neither the impetuous rapidity of the English charge, nor the Oriental dexterity in single combat. Their horses are deficient in action for the one purpose, and in suppleness for the other.

The peculiar merit of M. Baucher's system is, that it teaches us how this great difficulty can be successfully overcome. It begins by enabling the horseman to take complete possession of the horse's faculties while at rest and in slow motion. This ascendency, once gained, need never be lost; because a good horseman is always able to reduce his horse to that state in which it can be successfully reasserted. The horse is in this manner soon made to perceive that, if he escapes from the equilibrium required by his rider when at a pace which gives him the opportunity of doing so, he will immediately find himself brought back to a pace at which he may be forcibly prevented from doing so. And when he once understands this plain truth, his self-will is subdued for ever.

In order to exhaust the resources of this system, the horseman must of course possess 
an extraordinary natural share of that curious and indefinable quality which, for want of a better name, may be termed Physical Tact. But its distinguishing peculiarity is, that any man who knows how to manage an ordinary horse may apply it to a certain extent. Captain Nolan, an excellent judge and an experienced teacher of horsemanship, has declared his conviction that, by carefully observing $M$. Baucher's elementary precepts, an average horseman may, in about three months, bring an average horse to a degree of suppleness quite sufficient for all ordinary purposes. In what manner this can best be done we will now proceed to consider.

I. Balancing the Horse.-' One thing at a time' is the golden rule whose observance distinguishes M. Baucher's system from all its predecessors. First get complete command of your horse's attitude when at a halt, and then try to ride him on the move without letting him escape from your power. Pursue the same principle in order to get command of him when at a halt; that is to say, effect your purpose by getting command 
of one part of his body at a time. Begin with that part whose resistance you are able to subdue by mechanical force, and finish with that part whose submission must necessarily be more or less voluntary. In other words, begin by suppling your horse's crest, and then proceed to supple his haunches.

When your horse goes quite freely and steadily in the snaffle, equip him with a bit and bridoon, and take him to some place where there is nothing to divert his attention. Stand at his head, facing towards his near side, and holding the near bridoon rein in your left hand. Take both bit reins in your right hand, and hold them under his chin. Then draw your right hand gently but steadily towards his chest, at the same time restraining him with the left hand from stepping back or throwing up his head. After a very little hesitation he will give way to the pressure of the bit, arch his neck and champ the mouth-piece. Immediately drop the bit reins, and caress him with voice and hand. Renew the lesson after letting him rest for a few seconds, and continue it until 
he brings his head home at the slightest touch of the bit.

Next endeavour to get him in hand while mounted. Take up the bit rein and draw it smoothly towards you, until you feel a steady pressure upon the horse's mouth. Maintain this pressure without increase or diminution, until he drops his nose and plays with the bit; then slacken the rein and make much of him. Persevere until he opens his mouth and arches his neck at the first touch of the bit, without stiffening his body or shifting his legs. If he endeavours to avoid the pressure of the bit by stepping backwards, bring him back to his ground by a touch of the whip; and if he is obstinately fidgety, get an assistant to keep him in his place by holding the bridoon rein. But if you cautiously refrain from mounting him until you have fairly got him in hand on foot, this will seldom be necessary.

You have now complete command of your horse's forehand at a halt, and you have next to acquire equal power over his hind-quarters. This you must do by the use of the spur. Your horse has already learnt to answer the 
spur freely when in brisk movement, but you must not suppose that he is therefore necessarily prepared to endure it while kept collected and motionless. Begin by ascertaining that he does not mind the gradual closing and pressure of your legs and heels. Then try him with a pair of spurs whose rowels are covered with cloth or leather; and when he bears their application with indifference, put on a pair of ordinary heel spurs.

When he has learnt not to resist the spurs, he must next be taught to spring from them. Get him well in hand, and touch him lightly but firmly on both sides. If he kicks or winces, you are getting on too fast, and must return to the covered rowels, if not to the bare heels. If he continues calm and indifferent, increase very gradually the force of the application, or if necessary, which it seldom or never will be, use a pair of sharp hunting spurs. But if he tries to move forwards, carefully restrain him by the bridle, and then, dropping both your legs and hands, caress him and let him stand at ease. Repeat the lesson until the slightest pressure of your legs is sufficient to make him promptly collect 
himself and bring his hind legs under his body.

You have now laid a secure foundation, upon which you may continue to build until you have gradually completed your entire design. You are sure of being able to place and keep your horse, while at a halt, in the attitude which you wish him to preserve when on the move. You are also sure of being able to halt your horse whenever you please. $\mathrm{He}$ is therefore completely at your mercy. He cannot resist your hand except while advancing, and he cannot advance without your permission. All you have now to do is to make him understand that he will only be permitted to advance upon condition that, while doing so, he does not resist your hand.

Begin of course at the walk. Get him well collected at the halt; then slightly relax your hands, and let him move slowly forward. He will probably take advantage of the movement by stretching his neck as he steps off; immediately replace your hands and bring his head home, on the move if you can, at the halt if you must. In the latter case, give him a moment's pause for reflection 
before you repeat the lesson. Watch him narrowly while using your hands on the move, and meet him with your legs the moment you perceive that he is carrying back his weight instead of yielding his mouth. $\mathrm{He}$ will soon begin to find out that the former movement is always checked, and therefore that the latter, being the only alternative, must be desired.

When your horse advances quite collectedly at a walk, or, in other words, when you find that the pressure of your hand always brings his head home before it shortens his step, you may practise him at reining back: Get him collected at a halt as before, increase the pressure of your legs very gently, and the moment you feel that his weight is flowing forwards so that he can freely move his hind legs, use the hands to make him step backwards instead of advancing. As soon as he takes a single backward step, drop your hands and legs and make much of him. Continue the lesson until he takes three or four backward steps in succession, and repeat it until he reins back as easily and collectedly as he walks forward. 
You have now got your horse fairly in hand at a walk, and must proceed to effect the same purpose at a trot. Increase his pace very gently at first. You will find, however cautious you may be, that he no sooner strikes a trot than he stiffens his neck. Immediately meet him with your hands, and endeavour to play with his mouth so as to bring in his nose. If he shortens his pace instead of yielding his mouth, as at first he is sure to do, relax your hands very slightly and drive him forward by applying your legs. When he finds that he is not going to be allowed either to stiffen his crest or to shorten his pace, he will adopt the only alternative, and proceed at a trot with his head home.

You will, however, unless you are gifted with extraordinary natural tact, require considerable patience and perseverance before your horse goes contentedly in his new attitude. A horse which has just learnt to collect himself feels as awkward as a recruit who has just learnt to stand at 'attention,' and is as ready to relapse into his old lounging demeanour. The prompt use of the legs will be your principal resource. Whenever your horse begins to 
rake and bore against the bridle, keep your hand steady and touch him lightly with the spurs, so as to drive his haunches under him and take his weight off his fore legs. He will discover, as soon as his muscles become accustomed to the constraint of his new position, that he can go upon his haunches with more ease and safety to himself than he can upon his shoulders; and when he is quite convinced of this, your work is so far done.

2. Bending the Horse.-You have now, in a certain sense, got perfect command of your horse. You can drive him forward at your pleasure by your legs, and restrain him at your pleasure by your hand. $\mathrm{He}$ is therefore completely at your disposal, so long as you merely require him to carry you at a straightforward walk or trot. But convenience, not to say safety, will demand something more than this. To turn smartly, to step sideways freely, and to canter collectedly with either leg, are accomplishments which every horse deserving to be called a clever hack may fairly be expected to possess. We will now consider in what manner a horse which is already well 
balanced in his ordinary paces can most readily be taught them.

A horse, in order to move sideways in proper form, must gently curve his neck aside so as to look in the direction to which he is stepping. But this you must not at first expect. His natural impulse will be to make the movement of his haunches easier by looking the opposite way, as hewould if he were about to countershift his forehand and pivot upon his centre. You must therefore, before you attempt to combine the shifting of the haunches and the turn of the head in the proper manner, first make him familiar with the two movements separately, and next permit him to combine them in the manner most easy and convenient to himself.

Begin, as before, by bending his neck sideways on foot. Stand at his head, and take the bit reins one in each hand. Then draw the inner rein steadily to the front and the outer rein to the rear, continuing the pressure until the horse yields to it by turning his head and looking away from you. The moment he does this, relax both hands and caress him. Continue and repeat the lesson until he bends 
his neck either way so as to look full to his rear, and champs the bit the moment he feels it turned in his mouth. Then mount him, divide the reins, collect him at the halt, and try to bend him in the same manner by a steady feeling first of one rein and then of the other.

When your horse bends sideways quite freely at the pressure of the inward rein upon his bit, endeavour to make him do so by the pressure of the outward rein upon his neck. First get him perfectly collected at the halt with the reins divided, and then endeavour to keep him so by feeling his mouth with the left (or right) hand so that you can just see his nostril on tha: side, while you slightly relax the right (or left) rein. When you succeed in this, raise the right (or left) hand and carry it across you until the right (or left) rein presses against the side of the horse's neck. And when he bends sideways in this manner as freely as in the former, take the reins in one hand and try to make him bend sideways by simply carrying your bridle hand first to one side and then to the other.

When you find, as with tact and patience 
you very soon will, that you can place your horse's head to the right or left by the mere touch of the opposite rein, it is time to teach him how to shift his hind quarters. Collect him as before, and then gradually close one leg to his flank behind the girths. Maintain and increase the pressure, assisting it if necessary by a touch of the whip or spur, until he begins to circle on his fore legs in the opposite direction. The moment he makes a decided step from the leg, let him stand at ease and caress him. Continue the lesson until he has thus executed a complete circle to each hand; and repeat it until he circles smartly and easily, without attempting to stiffen his crest or shift his fore legs. Permit him during this interval, or if necessary assist him, to bend his neck and turn his head towards the leg from whose pressure he is moving his hind quarters.

When you are successful in this lesson, and not till then, endeavour to circle your horse upon his forehand with his neck bent and his head looking in the same direction. This is a position which most horses are at first very reluctant to maintain, and which must 
therefore be taught with great gentleness and patience. But it is a position which must be learnt; because no horse which has not learnt it can attempt, without imminent danger of falling, to wheel or circle at the gallop or full trot. Begin by circling the horse by the leg alone, without assisting him by turning his head in the opposite direction; then turn his head slightly to the right (or left) after every step which he makes in that direction; and finally try to circle him completely in the same position.

When your horse circles easily on his forehand with his head looking the right way, you will have no difficulty in making him circle or pirokette on his hind quarters. Collect him at the halt, and close both legs as if to make him step forward at a walk, at the same time carrying his forehand to the right (or left) by turning his head with the rein, and preventing him from throwing out his haunches the other way by applying the left (or right) leg behind the girths. Your legs, being now required to keep the horse's hind quarters motionless and not to shift them, must of course be used with some degree of nicety, or 
they will destroy the regularity of the horse's action by making him move forwards or shift his croup inwards. But if you commence the movement very slowly and carefully, you will soon acquire the necessary tact.

You have now got perfect command of your horse at the halt, and must proceed to effect the same purpose at a walk. Get him to move quite collectedly, and make him circle alternately upon his hind and fore legs; which he will very soon do with perfect ease, because the pair of legs upon which he circles must necessarily be halted for the purpose. Then try him with the half-passage, or oblique side-step. Collect him at the walk, turn his head gently to the right (or left) with the rein, and apply the opposite leg to make him shift his hind quarters in the same direction. In proportion to your success in doing this, make him gain ground more and more to the side and less and less to the front, until at length he passages as squarely as the necessity of crossing his legs will permit. Finally, endeavour by the same means to make him step off at the passage or half-passage from a collected halt. 
When you can do what you please with your horse at a walk, you may, if you think proper, proceed to circle and passage him at a trot; but this is by no means a necessary accomplishment. The only indispensable lesson which remains, is the canter with alternate legs. When you have got your horse quite collected at the walk and trot, he will probably make no resistance to being ridden at a collected canter or gallop, so long as he is permitted to strike off with whichever leg he prefers. If therefore you wish him to lead with one leg in preference to the other, you have only to urge and collect him until you feel him prepared to strike a canter, throw him into such a position that he must necessarily carry forward the preferable leg, and let him go.

What, then, is this position to be? My answer is, that the horse must be placed with his head looking full in the direction of his intended course, but with his croup thrown somewhat aside towards the leg with which he is to lead. If, for instance, I wished my horse to canter due north with the right leg leading, I would place him with his chest 
square to the north-north-west and his tail to the south-south-east, at the same time turning his head aside so as to keep his face full to the north. He would then, if previously prepared to strike a canter, find that the advanced position of his right shoulder and haunch compelled him to do so by throwing forward the right fore and hind legs.

You must however remember in cantering, as in circling and passaging, that very few horses can be induced to execute a lateral movement with the head looking and the croup moving the same way, until they have been allowed to practise it with the head averted. You must also remember that, although the horse's body is to be placed across the line of his intended course in order to make him strike off with the required leg, it must nevertheless become perfectly square to the front immediately after he has done so. Many horses will only canter at the half-passage - a fault which is usually due to the rider's negligence in not insisting upon the correct position of the head as soon as the horse begins to strike off easily the other way.

Now that vou know what is to be done, 
you will have no great difficulty in doing it. Collect your horse at the walk or short trot, until you feel him prepared to spring forward; then place him by carrying your hand to the left (or right).and applying the left (or right) leg, and when he throws forward his right (or left) fore leg, let him out straight. When he strikes off quite easily in this manner, carry your hand to the right (or left) while applying the left (or right) leg; and let him out as before; and when he is perfect at this, but not sooner, try by the same means to place him, while cantering with one leg, in the position which requires him to throw forward the other. If you find any difficulty in doing this, it will almost always be because you attempt it at a moment when the horse is not sufficiently collected in his canter.

3. Additional Remarks.-Whoever consults M. Baucher's own explanation of his system will find that, in giving my advice respecting its application, I have introduced several more or less important innovations. I trust that nobody will be so uncandid as to ascribe this to any doubt on my part of M. Baucher's 
superior judgment or experience. I do not hesitate to acknowledge his authority as plenary and conclusive, so far as the interest of the horse alone is concerned. But it must be remembered that I have at present something more to bear in mind. I have to consider, not merely how the English horse can be most effectually educated, but how far the English horseman can be persuaded to take the trouble of educating him. If we insist too rigorously upon getting our horses suppled in the best possible manner, the end of it will be that we shall not get them suppled at all.

M. Baucher would undertake to supple the young horse as soon as he has been successfully broken. He would begin by bending his neck with the bit, first sideways and then directly. He would then proceed to supple his haunches by circling him, first on the forehand and next on the hind quarters. $\mathrm{He}$ would afterwards get him completely in hand by reining him back and by using the spur at the halt. And finally he would ride him at the collected walk, trot and gallop successively; including, of course, lessons in circling on the move, passaging and cantering 
with alternate legs. $\mathrm{He}$ is of opinion that a scientific horseman, proceeding upon this plan, ought to complete the education of an average horse in one hundred and fifty lessons of half-an-hour each, given twice a day during seventy-five successive days.

If you are resolved to educate your horse as quickly and as perfectly as possible, you cannot do better than attempt it upon this plan. The rough and ready course of instruction which I have suggested is very far from promising equally speedy results. Following my advice, you ought to be quite satisfied if you are able to get your horse light in hand in a month, and to drive his haunches under him in another month; and we have already seen that, even when the foundation has thus been laid, all the finer and more complicated parts of his education are still before him. Considering, then, how much his progress in these difficult lessons will naturally be delayed by the distractions and excitements unavoidable while working in the open air, I think you will do well if, in six or even eight months, you make him as clever as his and your qualifications will allow. 
Now consider which of these two plans you prefer. Three months will give you a perfect horse upon M. Baucher's system pure and simple; but they will be three months of strict seclusion and solitary drudgery. The horse must divide his existence between the stable and the riding-school, until you have taught him all you can. Six months at least will be required to give you an equally perfect horse upon the system which I have ventured to recommend; but they will be six months of pleasurable exercise or of profitable service. They will not subtract a single hour from your enjoyment, or from your horse's utility. Which plan will be intrinsically the better I have very little doubt; but I have as little which plan you are the more likely to persevere in fulfilling.

I am perhaps presumptuous in assuming that there will be little or no difference, in point of ultimate success, between these two courses of similar instruction. But my reason for doing so is my implicit confidence in the principles which M. Baucher has himself laid down. Once make your horse feel that you are his master - that he must go forward when you drive him, and that he cannot go forward 
if you restrain him - and all the rest is a mere question of time and degree. You have then got him fairly between your hands and legs; and what you will do with him while he stays there, or how you can most effectually make him understand what you mean to do with him, are points which you may consider at your leisure. First disable your servant from hurting you, and then teach him to obey you.

I need scarcely point out that these arguments are not meant to disparage the plan of instruction recommended by $\mathrm{M}$. Baucher. They contain no objection whatever to that plan, when practised, as M. Baucher meant it to be practised, by the patient and cautious écuyer in his quiet riding-school. But the situation of the English sportsman is a very different one. He cannot and will not suspend his accustomed pursuits; his hack or hunter may require instruction, but in the meantime they must go. It is only reasonable that, in giving advice to horsemen of this character, I should recommend safety first and perfection afterwards. If you cannot prevent your horse from breaking your neck at the gallop, you will find little consolation in his admirable grace and docility at the halt or walk. 


\section{CHAPTER VII.}

FINISHING THE HORSE.

A HACK or roadster may be considered as sufficiently suppled for all ordinary purposes, when he has learnt to go quite freely and collectedly at a straightforward walk, trot and gallop, and likewise to circle, passage and rein back with perfect ease at a walk. Nor indeed can an ordinary horseman, although a good and scientific one so far as he goes, rely upon his own possession of the delicate tact which is necessary to make a horse preserve the correct action of the trot or canter while working sideways, backwards or at the halt. I think, therefore, that the subject of suppling the horse, so far as it concerns all horses alike, is exhausted by the preceding chapter.

Indeed it will generally be thought, that in saying this I am within the mark. There are several descriptions of horse in whose education the method of suppling recommended by 
M. Baucher might easily appear superfluous if not injurious. The object of that method is, as we have seen, to balance the horse upon his centre, so that his forehand and haunches shall shift lightly and easily at the slightest impulse. Now there certainly are purposes for which a horse may be used, whose effectual fulfilment requires him to throw his weight vigorously upon his forehand; and no doubt it is a natural inference that such purposes will be best achieved by a horse which has not been taught to balance his weight upon his centre.

All horses used exclusively for harness are instances of this kind. They cannot draw smoothly, or avoid perpetual shocks and jerks, unless they learn to carry forward their weight and set it steadily against the collar. But surely a docile and well-shaped horse might be made to acquire this knack without losing the equally important one of sinking his haunches and bringing his hind legs under his body. We are apt to forget how essential this latter faculty may be to the safety of an animal which has frequently to descend steep hills with a heavy carriage pressing upon 
his croup. That our present system of breaking draught-horses spoils them for the saddle, and that it even disfigures them when in harness unless manacled by the irksome bearingrein, are comparatively slight objections to it.

The race-horse is another example of the same kind. It is thought that by attempting to collect his paces we should run the risk of crippling that headlong rush of speed which makes, as 'Harry Hieover' truly says, the only real difference between a valuable horse and an invaluable phenomenon. The subject is one upon which I wish to speak with the diffidence becoming a person wholly unacquainted with the turf. But I think no horseman who has ever witnessed a false start for the Derby, or who has ever examined the fore legs of an aged race-horse, will deny that the sacrifice of suppleness to speed is a terrible one, or that a prudent trainer ought, before he makes it, to be quite sure that it is absolutely necessary.

There are, on the other hand, certain descriptions of horse which require the ordinary process of suppling and something more; that is to say, there are purposes for which a 
horse may be habitually used, whose effectual performance requires a special additional education. It does not, however, necessarily follow that the superintendence of this additional education is a task of extraordinary difficulty, or demands any degree of equestrian tact which a man of average faculties cannot with practice and attention make sure of acquiring. I have therefore, in the present chapter, added to my work a few leading hints upon the subject.

I. Finishing the Hunter.-I need scarcely point out that, if the ordinary process of suppling is necessary or useful for a hack, it must be still more so for a hunter. If a horse which is not well balanced and light in hand cannot carry his rider with safety or comfort when trotting along a high road, far less can he do so when galloping over Surrey hills or Hampshire morasses. But a hunter, as we all know, requires instruction which a hack does not. A first-flight horseman expects his horse to face almost any fence which the hands of man can set up ; and even an average rider to hounds cannot be safely carried 
by an animal which is not perfectly able to clear an ordinary hedge and ditch. No horse is therefore fit to be called a hunter which is not a steady and practised leaper.

Begin by teaching your horse how to exert his natural powers of leaping. It is true that any active horse knows how to gallop over a fence, if frightened or forced into doing so. But there are very few young horses, and not very many old hunters, who know how to execute a high standing jump. In order to do this, a horse must have learnt by experience how to sink upon his haunches and bound into the air; and this is a knack which, simple and natural as in itself it is, he will never acquire so long as he is compelled or allowed to practise leaping in a state of alarm or excitement. And yet every sportsman knows that there are many hunting countries in which no man who values his life would think of riding a mere flying jumper, and that there are none in which a steady standing jumper is not often exceedingly useful.

There is, for instance, no English county in which the ordinary five-barred gate is not very common. The height of an average 
five-barred gate is about three feet nine inches; and a horse must therefore, in order to clear an average five-barred gate with perfect safety, jump about four feet from the ground. Now I believe I speak within compass when I say that the steadiest horse will seldom, in leaping at the gallop, take off at a distance from his fence less than double its height. And therefore every horse which gallops at a fivebarred gate must do so with the knowledge that, if he fails to clear at least sixteen feet in his stride, he is pretty sure to get a very violent fall.

Now look at the alternative. No horse, however deep chested, stands higher from his brisket to his withers than from the ground to his brisket. A horse of fifteen hands will therefore, when standing on all four feet, show at least thirty inches of daylight under his brisket, and can consequently, allowing him a few inches for gathering up his legs, step without raising his body over a fence full two feet high. A horse of fifteen hands is thus sure of clearing a five-barred gate by a standing jump, if he can but throw his croup two feet in the air and at the same 
time propel his body its own length in advance. This is an achievement which, I venture to affirm, any tolerably active bullock could easily learn to perform.

Make a leaping-bar with a long heavy pole and a few stout hurdles. Muffle the bar, and if necessary thatch the hurdles, with furze. Lay the bar on the ground, and set up the hurdles so as to form a lane leading to it. Then lead the horse across it in a lunge. Let him tread upon it or blunder over it if he likes; the furze will soon teach him to jump it. If he refuses, let an attendant follow him with a long whip; but take care that the horse is not unnecessarily struck or frightened. When he hops quietly over the bar upon the ground, begin to raise it by means of the hurdle-bars, a few inches at a time, until it is as high as a gate. And when he jumps this height steadily, lay down another bar seven or eight feet beyond the first, and raise it gradually as before.

Better judges than I can pretend to be are of opinion that the leaping-bar should be fixed, so as to throw down the horse if he fails to clear it. In some cases this may be 
necessary, but I own I should be reluctant to try it. I should expect the effect of a heavy fall over a fixed bar to be, that the horse would for a long time be so thoroughly terrified as to be unable to jump at all. Now the pain caused by striking a heavy furzeclad bar hard enough to throw it down is just sufficient to rouse and startle without unnerving him, much as a hard stroke with the whip or spurs might do. I therefore am inclined to think that, in any ordinary case, it would be quite sufficient.

When your horse jumps the double bar quite cleverly, it is time to make him familiar with different kinds of fences. Lead him about the fields in a lunge, and let him scramble overthem his own way. The variety which he is likely to encounter in hunting is not very great. Hedge and ditch, bank and ditch, stone wall, timber, water - and the list is nearly complete. Pick out, of course, the smallest specimens you can find. Your object is to make him cool and clever, not to show off his elasticity. Be particular, above all, in giving him plenty of practice over gaps, grips, blind ditches, and other such 
nondescript obstacles. They are very easy to get over in the right way, and very dangerous if attempted in the wrong.

Your horse is now fit to be taken out hunting. But do not expect him to be a complete, or even a safe hunter, until he is familiar with the excitement of the field. How soon he will become so must in a great measure depend upon his natural temper. But you will materially shorten his education if you are careful to protect him from the risk of getting falls or feeling distress, so long as he shows signs of timidity or impetuosity. Begin by taking him home after he has had a good gallop. Then let him attempt a certain number of easy fences. A little self-denial at first will be amply rewarded in the long run; and you will find that, with no serious danger and with only an average exertion of skill, you will have made your horse an accomplished hunter for any country.

2. Finishing the Charger. - The best tacticians are agreed that the most essential quality of cavalry is the speed and weight of their charge. What the musket is to the 
footsoldier, said Frederick of Prussia, that is the spur to the horseman. The Cymry, says the old Welsh proverb, fight with the sword, and the Normans with the horse's shoulder. The English military authorities have the great merit of being the only ones in the world who understand this important truth. They take care to make their troopers firm and bold riders, and to mount them upon swift and powerful horses; and the consequence is, that the English charge is acknowledged to be almost irresistible.

This, however, is only half what is required. A cavalry regiment which can charge, but cannot rally after charging, resembles a piece of artillery which can be fired but cannot be reloaded; and no cavalry, whose horses have not been properly suppled, can rally with expedition after charging. Not only will it take a long time to pull up and bring back a number of vigorous and fiery animals, maddened by the excitement of the rush and shock and unaccustomed to yield implicit obedience to their riders, but the scattered troopers are likely to suffer heavy loss from being cut up in detail by their more agile 
though less powerful opponents, if not to incur utter destruction from being charged by a fresh enemy while still in disorder.

This, we all know, is the vulnerable point of the English cavalry. One crushing, smashing charge, usually exhausts their powers. The men straggle slowly back with blown and tired horses, after miles of unnecessary galloping and hecatombs of unnecessary loss ; and the brigade is unserviceable for the rest of the day. Nor is this all. The English trooper is by no means so formidable in single combat as his own great strength and courage, combined with that of his horse, ought to make him. With his blunt heavy broadsword and great pulling charger, he is almost at the mercy of the Sikh or Mahratta, with his keen scimitar and quick supple Arab, and is scarcely more than a match for the French dragoon, with his long rapier and docile galloway.

The reason of this is obvious. Except just so much bitting as is necessary to make him carry himself handsomely at the halt and walk, and just so much reining back and passaging as is necessary to place him properly 
in the ranks, the English troop-horse undergoes no suppling whatever. The men are not taught to get their horses in hand at speed, nor to practise them in circling or pirouetting at the short canter. The consequence is that in single combats none of our horses are under command, and that in a charge most of them are accustomed to run away.

Now there is no reason whatever why either of these inconveniences should continue to exist. The high spirit and powerful frame of the English charger make him peculiarly capable of pulling up short and of wheeling rapidly. All that is required is to make him understand that his rider wishes him to do so and so, and that what his rider wishes must be done. Nor is this more than can easily be effected by auy good scientific horseman; that is to say, by such a horseman as any man of average natural faculties may with proper instruction and due diligence make sure of becoming. Any cavalry officer may therefore, if he pleases, make his own horse a perfect charger.

Every saddle horse ought to be light in 


\section{Finishing the Horse.}

hand at the canter; and a horse which is light in hand at the canter is easily got in hand at full speed. Increase his pace by degrees, alternately letting him out and shortening his stride, by first applying the legs or spurs and then pulling at his mouth. He will soon learn, however fast he may be going, to bring his haunches under him the moment he feels the legs. The rest is a mere question of time and degree. Any horse may be taught, in a very short time, to collect himself and come to the halt in a few strides when at full speed; and any horse which is naturally strong and supple in the hind-quarters may be taught to throw himself on his haunches and stop dead short without risk of injury.

A single combat on horseback is nothing but a trial of skill, which of the combatants shall first succeed in bringing his sword-hand to bear upon the near or unprotected side of his antagonist. Such combats are therefore wholly decided by horsemanship. The best swordsman will be entirely helpless if he cannot manage his horse, because he can neither reach his enemy nor defend himself with his sword-arm thrown across his body; and the 
worst swordsman, if he does but know how to strike with the edge or to thrust with the point of his weapon, can easily cut down or run through an opponent who allows himself to be attacked upon the bridle-hand.

It is found by experience that the short canter is the pace at which a horse can wheel or circle with the greatest ease and rapidity. Any well-made horse can easily be taught to canter truly and steadily at a pace not exceeding five or six miles an hour. Prevail upon your horse to do this, commencing with either leg and changing legs at your pleasure, and your object is gained. A very little practice will perfect him in turning short on his haunches to either hand, and then springing forward without breaking his stride; and you may even teach him, if you think it worth while, to execute a complete semi-circle upon his hind legs with his fore feet suspended in the air.

It was truly and generously observed by Marshal Soult, that the English cavalry, if they were but taught to supple their horses according to M. Baucher's system, would be the most formidable that ever existed; be- 
cause they would retain their characteristic speed and power, without, as at present, sacrificing to it the docility of the individual charger. It is easy to understand the great superiority which the English dragoon would, if thoroughly master of his horse, possess over enemies whom he can overturn with a single shock, and whom he can leave behind him in a dozen strides. The traditions of our Indian army abound in brilliant proofs of the formidable prowess which our self-taught champions often obtain; nor is there any reason to doubt that the exploits of Dallas, Hodson and Chamberlayne might, with a proper system of instruction, be rivalled by many of our private troopers. 


\section{Conclusion.}

The lessons which I have now prescribed will in my opinion suffice, if carefully practised, to make in a few months a perfect horseman upon a perfect horse. But this high-sounding phrase must not be misunderstood. By a perfect horseman or horse I only mean a horseman or horse who has learned to use his natural faculties to the best possible advantage for the purpose of riding or being ridden; and I need scarcely point out that the natural faculties of many horsemen and horses are of a very humble order, . or that a given style of riding or being ridden may be relatively speaking perfect, and yet absolutely speaking by no means conspicuously brilliant.

Brilliant riding is common enough in England-perfect riding is extremely rare. We have plenty of men and horses who can perform particular feats with a courage and dexterity such as the whole world might 
safely be defied to excel; but we have very few men and very few horses who understand how to perform all the manœuvres required in ordinary riding. A horseman of average nerve and tact will therefore, if he has taken the trouble to make the best of himself and his horse, find himself a match upon the whole for men who are naturally much his superiors; just as the poking, painstaking gunner, who has learnt to make sure of a deliberate shot, will usually bring home quite as good a bag as his more dexterous but less laborious rivals.

Indeed, I might say more than this. The peculiar pleasure and charm of scientific horsemanship is, that the man who is beginning to understand it never gets on horseback without being conscious that he is improving either himself or his horse. He will therefore find a satisfaction in ordinary riding which more ambitious but less scientific horsemen are unable to comprehend; because he perceives, and they do not, how intimately equestrian prowess is connected with mechanical detail. Of the pleasure which a perfect horseman feels in riding a perfect horse edu- 
cated by himself, I cannot pretend to speak from experience; but I can easily believe that my utmost enjoyment in the exercise is, compared to that described by M. Baucher, ' as moonlight unto sunlight, or as water unto wine.'

I have but a few more words to say. Many of our English sporting writers are accustomed to speak with not unnatural derision of what they call the Continental style of riding. They are fond of contrasting the crippled action and cowed or embittered temper of the highlybroken foreign charger with the free step and generous spirit of the English hunter. I dare say we all remember Mr. Clarke's amusing account of the vicious Hungarian pony, which had been curbed and spurred by the German cavalry officers until he kicked them all off in succession, but which immediately submitted to the English fox-hunter, who sat quietly on his back and just felt his mouth with the snaffle.

There is, no doubt, much justice in these criticisms. It is quite true that, if you want to make your horse a surly rebel, you cannot 
do so more effectually than by attempting to collect him by the forcible use of the curb and spurs before he has learnt to understand what they mean. It is equally true that, if you want to make him a curby-hocked and brokenspirited cripple, you have only to insist upon perpetually keeping him collected with his and your weight upon his hind legs. And, finally, it is too certain that both these blunders have long been systematically taught, and are still to some extent habitually committed, by Continental manége-riders.

But remember that there is a reverse to the medal. A horse which has not been taught to spring from the spurs and yield to the bit may carry you, but you cannot ride him. He may go very pleasantly under you so long as his opinion upon things in general happens to agree with yours; but let him once get frightened or excited, and you will soon find that it requires all your strength and nerve to manage him. Such a horse, however quiet and good-tempered he may be, can never be really safe to ride; because he has not lost the power of defying his rider. You cannot, if he does 
begin to rebel, throw him into an attitude in which he is unable to resist you.

Men who have never felt what danger on horseback means may sneer at these arguments if they choose. Men who know what it is to ride a star-gazing rusher at a double fence will listen to them in a different spirit. It is, in fact, the bold and dashing rider who requires to have a thoroughly broken horse. Your elderly heavy-weight may jog along the turnpike-road all his life, without ever finding out whether his corpulent cob has been properly broken or not. It is therefore the English fox-hunter to whom, above all mortal men, the hints contained in this little work may, if he chooses to make them so, become practically important.

Why is it that every hunting man who values his neck takes such pains and pays such prices to secure 'made' hunters? A made hunter does nothing which any welleducated horse of equal.natural powers could not, if taught confidence by a little practice in fencing and coolness by a few days with hounds, be compelled by any scientific horse- 
man to do. But the truth is, that an English hunter is scarcely ever decently educated; and an Englishman who wants to be safely carried across country must therefore procure a horse which, from long practice and from skilful riding, has lost the inclination either to refuse his fences or to take them carelessly.

The common sense of the matter is simply this. There is a medium in horse-breaking as in all other things. Teaching a horse to collect himself is one thing; and torturing an untaught horse in order to make him collect himself is another. Collecting a well-taught horse at intervals during a two hours' airing is one thing; and forcing him to dance upon his hind legs throughout a long day's journey is another. He will understand this as well as you do. Make him perceive that you are only asking him to learn one easy lesson at a time, and he will take as much pride in displaying his strength and beauty as you can.

In order to effect this you will only require an average share of natural good temper, and a thorough love and enjoyment of horses and horsemanship. Patience and attention will 
give you mechanical skill, if they cannot supply its place. Keep your horse and yoursel1 in good humour; and your final success will, in most cases, be only a question of time. Assure yourself that all your disappointments are your fault and not his. Be lavish of caresses and rewards when he submits, and of pauses for rest and reflection when he resists. Bear in mind that you are working with and for, not against him, and that if you cannot persuade him of this you will effect nothing whatever.

Do not, above all, be in haste to condemn your horse for final impenitence. There are very few horses which cannot be properly suppled-still fewer which will not be greatly and manifestly improved by even an imperfect attempt to supple them. If you find that you are making no progress, it is twenty to one that the fault is your own. Try every possible combination before you give up. Remember that every lesson, carefully and patiently given, will improve you in teaching, if it does not improve your pupil in learning. Above all, never give up in a pet. So long as you feel mortified and dissatisfied 
at your failure, this is a sure proof that your failure was avoidable and is reparable. When you are complacently conscious of having done your own work cleverly and well, then lay the blame upon your horse if you choose to do so. 
184.

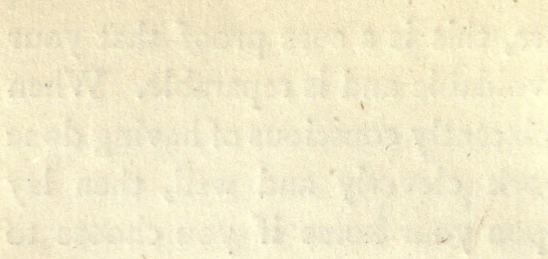


[SEPTEMBER 1868.」

\section{GENERAL IIST OF WORKS}

POBLISHED BY

\section{MESSRS. LONGMANS, GREEN, AND CO.}

\section{PATERNOSTER ROW, LONDON.}

andparea

\section{Historical Works.}

LORD MACAULAY'S WORKS. Complete and Uniform Library Edition. Edited by his Sister, Lady Trevelyan. 8 vols. 8vo. with Portrait, price $£ 55 s$. cloth, or $£ 88 s$. bound in tree-calf by Riviere.

The HISTORY of ENGLAND from the Fall of Wolsey to the Death of Elizabeth. By JaMes Anthony Froude. M.A. late Fellow of Exeter College, Oxford. Vous. 1. to X. in 8vo. price $£ 72$ s. cloth.

Vors. I. to IV. the Reign of Henry VIII. Third Edition, 54s.

VoLs. V. and VI. the Reigns of Edward VI. and Mary. Third Edition, 28s.

Vols. VII. and VIII. the Reign of Elizabeth, Vols. I. and II. Fourth Edition, 28s.

Vols. IX. and X. the Reign of Elizabeth, Vocs. III. and IV. 32s.

The HISTORY of ENGLAND from the Accession of James II.

Lord MACAULAY.

LIBRARY EDITION, 5 vols. 8vo. $£ 4$.

CABINet Edition, 8 vols. post 8 vo. 48 s.

PEOPLE's Edition, 4 vols. crown 8vo. $16 s$.

REVOLUTIONS in ENGLISH HISTORY. By ROBERT VAUGHAN, D.D. 3 vols. 8 vo. 30 s.

The GOVERNMENT of ENGLAND : its Structure and its Development. By WiLLIAM EDWARD HEARN, LLD. Professor of History and Political Economy in the Uuiversity of Melbourne. 8vo. 14s.

PLUTOLOGY; or, the Theory of the. Efforts to Satisfy Human Wants. By the same Author. 8vo.14s.

An ESSAY on the HISTORY of the ENGLISH GOVERNMENT and Constitution, from the Reign of Henry VII. to the Present Time. By JoHN EARI RUSSELI. Fourth Edition, revised. Crown 8vo, 6s.

On PARLIAMENTARY GOVERNMENT in ENGLAND: Its Origin, Development, and Practical Operation. By ALPHEUS TODD, Librarian of the Legislative Assembly of Caulada. In Two Volumes. VoL. I. Sro. 16s. 
The ENGLish REFORMATION. By F. C. Massingberd, M.A. Chancellor of Lincoln and Rector of South Ormsby. Fourth Edition, revised. Fcp. 8vo. 7s. $6 d$.

HISTORY Of WESLEYAN METHODISM. By GEORGE SMTH, F.A.S. Fourth Edition, with numerous Portraits. 3 vols. cr. 8 vo. 78 . each.

\section{Biography and Memoirs.}

DICTIONARY of GENERAL BIOGRAPHY; containing Concise Memoirs and Notices of the most Eminent Persons of all Countries, from the Earliest Ages to the Present Time. Edited by W. L. R. CATES. 8Vo. 21s.

MEMOIRS of Sir PHILIP FRANCIS, K.C.B. with Correspondence and Journals. Commenced by the late JOSEPI PARKES; completed and edited by Herman Merivale, M.A. 2 vols. 8vo. with Purtrait and Facsimiles, $30 s$.

A MEMOIR of BARON BUNSEN, late Minister Plenipotentiary and Envoy Extraordinary of tho King of Prussia at the British Court. Extracted from Family Sources by his Widow, Baroness Bunsen. With 'Two Portraits and several Lithographi: Views. 2 vols. 8 vo. $42 s$.

IIFE and CORRESPONDENCE of RICHARD WHATELY, D.D. late Archbishop of Dublin. By E. JANE WHATELY. Popular Edition, with Additions and Omissions. Crown 8vo. with Portrait, 7s. $6 d$.

EXTRACTS of the JOURNAIS and CORRESPONDENCE of MISS BERRY, from the Year 1783 to 1852. Edited by Lady TherESA LEWIS. Second Edition, with 3 Portraits. 3 vols. 8 vo. $42 s$.

LIFE of the DUKE of WELLINGTON. By the Rev. G. R. GLEIG, M.A. Popular Edition, carefully revised; with copious Additions. Crown 8vo. with Portrait, $5 s$.

HISTORY of MY RELIGIOUS OPINIONS. By J. H. NEwMAN, D.D. Being the Substance of A pologia pro Vita Sua. Post 8vo. 6s.

FATHER MATHEW: a Biography. By Jomn Francis Maguire, M.P. for Cork. Popular Edition, with Portrait. Crown 8vo. 3s.6d.

Rome; its Rulers and its Institutions. By the same Author. New Edition nearly ready.

LETTERS of DISTINGUISHED MUSICIANS, viz. Gluck, Haydn, P. E. Bach, Weber. and Mendelssohn. Tran-lated from the German by Lady WALLACE. With Three Portraits. Post 8vo. 14s.

FELIX MENDELSSOFN'S LETTERS from Italy and Switzerland, and Letters from 1833 to 1847, translatcd by Lady WALLACE. New Edition, with Portrait. 2 vols. crown Svo. 5s. each.

MOZART'S LETTERS (1769-1791), translated from the Collection of Dr. LUDWig Norru by Lady Wallace. 2 vols. post 8vo. with Portrait and Facsimile, 18s.

BEETHOVEN'S IETTERS (1790-1826), Tronslated from the Collection of Dr. NoHr by Lady WALLACE. 2 vols, post $8 \mathrm{vo}$. with Portrait, $18 s$. 
FARADAY as a DISCOVERER. By JoHN TrNDALL, LL.D. F.R.S. Professor of Natural Philosophy in the Royal Institution of Great Britain. With Two Portraits. Crown 8vo. tis.

MEMOIRS of SIR HENRY HAVELOCK, K.C.B. By JOHN CLARK Marshman. Cabinet Edition, with Portrait. Crown 8vo.price $5 s$.

IIFE of PASTOR FLIEDNER, Founder of the Deaconesses' Institution at Kaiserswerth. Translated from the German by CATHERINE WINK. WORTH. F.p. 8 vo. with Portrait, $3 s .6 d$.

LIFE of FRANZ SCHUBERT, translated from the German of Keitzle Von Hellborn by Arthor Duke Coleridge, M.A. late Fellow of King's College, Cambridge. [Nearly ready.

WITH MAXIMILIAN in MEXICO. From the Note-Book of a Mexican Officer. By Max. Baron Von ALVEnsLeben, late Lieutenant in the Imperial Mexican Army. Post 8io. $7 s .6 d$.

VICISSITUDES of FAMILIES. By Sir BERNARD BURKE, Ulster King of Arms. First, SECOND, and THIRD SERIEs. 3 vols. crown $8 v 0$. 12s. $6 d$. each.

ESSAYS in ECCLESIASTICAI BIOGRAPHY. By the Right Hon. SirJ. Stephen, LL.D. Cabinet Edition (being the Fifth). Crown 8vo.7s.6d.

MAUNDER'S BIOGRAPHICAL TREASURY. Thirteenth Edition, reconstructed, thoroughly revised, and in great part rewritten; with about 1,000 additional Memoirs and Notices, by W. L. R. CAtes. Fcp. 10s. $6 d$.

LETTERS and IIFE of FRANCIS BACON, including all his Occasional Works. Collected and edited, with a Commentary, by J. SPEDDING, Trin. Coll. Cantab. VoLs. I. and II. Svo.24s.

\section{Criticism, Philosophy, Polity, \&c.}

The INSTITUTES of JUSTINIAN; with English Introduction, Translation, and Notes. Bv T. C. SANDARS, M.A. Barrister, late Fellow of Oriel Coll. Oxon. Third Edition. 8vo. 15s.

The ETHICS of ARISTOTLE, illustrated with Essays and Notes. By Sir A. Grant, Bart. M.A. LL.D. Second Edition, revised and completed. 2 vols. 8 vo.price $28 s$.

ELEMENTS of LOGIC. By R. Whately, D.D. late Archbishop of Dublin. Ninth Edition. 8vo. $10 s .6 d$. crown 8vo. 4s. $6 d$.

Elements of Rhetoric. By the same Author. Seventh Edition. 8 vo. 10 s. $6 d$. crown 8 vo. $4 s .6 d$.

English Synonymes. Edited by Archbishop Whatelox. 5th Edition. Fcp. $3 s$.

BACON'S ESSAYS with ANNOTATIONS. By R. Whately, D.D. late Archbishop of Dublin. Sixth Edition. 8vo.10s. $6 d$. 
IORD BACON'S WORKS, collected and edited by R. I. ELLIS, M.A. J. Spedding, M.A. and D. D. HeAtr. Vols. I. to V. Philosophrcal Works, 5 vols. 8vo. £4 6s. Vols. VI. and VII. Literary and Professional Works, 2 vols. $£ 116 s$.

On REPRESENTATIVE GOVERNMENT. By JoHN StoARt Mill, M.P. for Westminster. Third Edition, 8vo. 9s. crown 8vo. $2 s$.

On IIBERTY. By John Stuart MiLc, M.P. for Westminster. Third Edition. Post 8vo. 7s. $6 d$. crown 8 vo. 1 s. $4 d$.

Principles of Political Economy. By the same Author. Sixth Edition. 2 vols. 8 vo. 30 s. or in 1 vol. crown 8 vo. $5 s$.

A System of Logic, Ratiocinative and Inductive. By the same Author. Seventh Edition. Two vols. 8vo. 25s.

Utilitarianism. By the same Author. Second Edition. 8vo. 5s.

Dissertations and Discussions, Political, Philosophical, and Historical. By the same Author. Second Edition, revised. 3 vols. 8 vo. $36 s$.

Examination of Sir W. Hamilton's Philosophy, and of the Principal Philosophical Questions discussed in his Writings. By the same Author. Third Edition. 8vo. 16s.

WORKMEN and WAGES at HOME and ABROAD; or, the Effects of Strikes, Combinations, and Trade Unions. By J. WARD, Author of 'The World in its Workshops,' \&c. Post 8vo. 7s. $6 d$.

The ELEMENTS of POLITICAL ECONOMT. By Henry Dunning MACLEOD, M.A. Barrister-at-Law. 8vo.16s.

A Dictionary of Political Economy; Biographical, Bibliographical, Historical, and Practical. By the same Author. Vor. I. royal 8vo. 30s.

An OUTLINE of the NECESSARY IAWS of THOUGHT: a Treatise on Pure and Applied Logic. By the Most Rev. William, Lord Archbishop of York, D.D. F.R.S. Ninth Thousand. Crown 8vo. 5s. $6 d$.

ANALYSIS of Mr. MILL'S SYSTEM of LOGIC. By W. STEBbiNe, M.A. Fellow of Worcester College, Oxford. Second Edition. 12mo. 3s. 6d.

The ELECTION of REPRESENTATIVES, Parliamentary and Municipal ; a Treatise. By THomAs HARE, Barrister-at-Law. Third Edition, with Additions. Crown 8vo.6s.

SPEECHES of the RIGHT HON. LORD MACAULAY, corrected by Himself. Library Edition, 8vo.12s. People's Edition, crown 8vo. 3s.6d.

LORD MACAULAY'S SPEECHES ON PARLIAMENTARY REFORM in 1831 and $1832.16 \mathrm{mo}$. $1 s$.

SPEECHES on PARLIAMENTARY REFORM, delivered in the House of Commons by the Riglit Hon. B. DisRaeli (1848-1863). Edited by Montagu Corry, B.A. Second Edition. 8vo.12s.

INAUGURAL ADDRESS delivered to the University of St. Andrews. By John Stuart Milc. 8vo. 5s. People's Edition, crown 8vo. 1s. 
A DICTIONARY of the ENGLISH LANGUAGE. By R. G. LATHAM, M.A. M.D. F.R.S. Founded on the Dictionary of Dr. S. Jomsson, as edited by the Rev. H. J. TODD, with numerous Emendations and Additions. In Two Volumes. Vor. I. 4to. in Two Parts, price $2310 s$. In course of publication, also, in 36 Parts, price $3 s .6 d$. each.

THESAURUS Of ENGLISH WORDS and PHRASES, classified and arranged so as to facilitate the Expression of Ideas, and assist in Literary Composition. By P. M. Roget, M.D. New Edition. Crowu 8vo. 10s.6d.

IECTURES on the SCIENCE of LANGUAGE, delivered at the Royal Institution. By MAX MUtLLER, M.A. Taylorian Professor in the University of Oxford. First Series, Fifth Edition, 12s. Second Series, 18s.

CHapters on IANGUAgE. By Frederic W. Farrar, F.R.S. late Fellow of Trin. Coll. Cambridge. Crown 8vo. $8 s .6 d$.

The DEBATER; a Series of Complete Debates, Outlines of Debates, and Questions for Discussion. By F. RowTon. Fcp. 68 .

A COURSE of ENGLISH READING, adapted to every taste and capacity; or, How and What to Read. By the Rev. J. PyckOrT, B.A. Fourth Edition. Fep. $5 s$.

MANUAL of ENGLISH IITERATURE, Historical and Critical. By THOMAS ARNoLD, M.A. Second Edition. Crown 8vo. price 7s.6d.

SOUTHEY'S DOCTOR, complete in One Volume. Edited by the Rev. J. W. W $A$ RTER, B.D. Square crown 8vo. 12s. $6 d$.

HISTORICAL and CRITICAL COMMENTARY on the OLD TESTAMENT; with a New Translation. By M. M. KalISCH, Ph.D. Vol. I. Genesis, 8vo. 18s. or adapted for the General Reader, 12s. Vor. II. Exodus, 15s, or adapted for the General Reader, 12s. VoL. III. Leviticus, PART I. 15s. or adapted for the General Reader, $8 s$.

A Hebrew Grammar, with Exercises. By the same Author. Part I. Outlines with Exercises, 8vo. 12s. 6d. KEY, 5s. PART II. Exceptional Forms and Constructions, $12 s .6 d$.

A LATIN-ENGIISH DICTIONARY. By J. T. White, D.D. of Corpus Christi College, and J. E. RIDDLE, M.A. of St. Edmund Hall, Oxford. Imperial 8vo. pp. 2,128, price 42s. cloth.

A New Latin-English Dictionary, abridged from the larger work of White and Riddle (as above), hy J. T. White, D.D. Joint-Author. Medium 8vo. pp. 1,048, price 18s. cloth.

The Junior Scholar's Latin-English Dictionary, abridged from the larger works of White and Riddle (as above), by J.T. White, D.D. surviving Joint.Author. Square $32 \mathrm{mo}$. pp. 662, price 7s.6d. cloth.

An ENGLISH-GREER IEXICON, containing all the Greek Words used by Writers of good authority. By C. D. YoNGE, B.A. Fifth Edition. 4to. $21 s$.

Mr. YONGE'S NEW LEXICON, English and Greek, abridged from his larger work (as above). Revised Edition. Square 12mo. 8s. $6 d$.

A GREEK-ENGLISH LEXICON. Compiled by H. G. LIDDELL, D.D. Dean of Christ Church, and R. ScotT, D.D. Master of Balliol. Fifth Edition. Crown 4to. 31s. $6 d$.

A Lexicon, Greek and English, abridged from LidDell and Scotr's Greek-English Lexicon. Eleventh Edition. Square 12mo. 7s. 6d. 
A SANSKRIT-ENGLISH DICTIONARY, the Sanskrit words printed both in the original Devanagari and in Roman letters. Compiled by T. Benfex, Prof, in the Univ. of Göttingen. 8vo. 52s. $6 d$.

A PRACTICAL DICTIONARY of the FRENCH and ENGLISH LANGUages. By L. Contanseat. Thirteenth Edition. Post 8vo. 10s.6d.

Contanseau's Pocket Dictionary, French and English, abridged from the above by the Author. New Edition, revised. Square 18mo. $3 s .6 d$.

NEW PRACTICAL DICTIONARY of the GERMAN LANGUAGE; German-English and English-German. By the Rev. W.L. BLACKLEx, M.A. and Dr. CARL MARTIN Friediënder. Chenper Issue, post 8vo. $7 s .6 d$.

\section{Miscellaneous Works and Popular Metaphysics.}

LESSONS of MIDDLE AGE, with some Account of various Cities and Men. By A.K. H. B. Author of "The Recrcations of a Country Parson." Post 8vo. 9s.

RECREATIONS of a COUNTRY PARSON. By A. K. H. B. New Editions, carefully revised. FInST and Second Series, crown 8vo. $3 s .6 d$. each.

The Common-place Philosopher in Town and Country. By the same Author. Crown 8vo. 3s. 6d.

Leisure Hours in Town; Essays Consolatory, Esthetical, Moral, Social, and Domestic. By the same Author. Crown 8vo.3s.6d.

The Autumn Holidays of a Country Parson; Essays contributed to Fraser's Mragazine and to Good Words. By the same. Crown 8vo. 3s.6d.

The Graver Thoughts of a Country Parson. By the same Author. FIRST and SECoNd SerIes, crown 8vo. 3s. 6d. each.

Critical Essays of a Country Parson. Selected from Essays contributed to Fraser's Magazine. By the same Author. Crown 8vo.3s. 6d.

Sunday Afternoons at the Parish Church of a Scottish University City. By the same Author. Crown 8vo. 3s, $6 d$.

Counsel and Comfort spoken from a City Pulpit. By the same Author. Crown 8vo. 3s. $6 d$.

SHORT STUDIES On GREAT SUBJECTS. By JAMES ANTHONY FrodDE, M.A. late Fullow of Exeter Coll. Oxford. Second Edition. 8vo. 12s.

STUDIES in PARLIAMENT. A Series of Sketches of Leading Politicians. By R. H. Hutton. Crown 8vo. $4 s, 6 d$.

LORD MACAOLAY'S MISCELLANEOUS WRITINGS.

LIBRARY EDITION. 2 vols. 8vo. Portrait, $21 s$.

People's Edition. 1 vol. crown 8vo. $4 s .6 d$.

The REV. SYDNEY SMITH'S MISCELLANEOUS WORKS ; including his Contributions to tho Edinburgh Revievo. 2 vols. crown 8vo. Ss.

Elementary Sketches of Moral Philosophy, delivered at the Royal Institution. By the Rev. SyDNEy Smitr, M.A. Fourth Edition. Fep. $6 s$. 
The Wit and Wisdom of the Rev. Sydney Smith: a Selection of the most memorable Passages in his Writings and Conversation. 16mo. 5s.

EPIGRAMS, Ancient and Modern ; Humorous, Witty, Satirical, Moral, and Panegyrical. Edited by Rev. JоHN BоOTH, B.A. Cambridge. Second Edition, revised and enlarged. Fcp. 7s. $6 d$.

From MATTER to SPIRIT: the Result of Ten Years' Experience in Spirit Manifestations. By SopHIA E. DE MORGAN. With a PrEFACE by her Husband, Professor DE Moras. Post 8vo. 8s. $6 d$.

The PEDIGREE of the ENGLISH PEOPLE; an Argument, Historical and Scientific, on the Ethnology of the English. By THOMAs Nicholas, M.A. Ph.D. 8vo. $16 s$.

The ENGIISH and THEIR ORIGIN : a Prologue to authentic English History. By LUKE OWEN PIKE, M.A. Barrister-at-Law. 8vo. 9s.

ESSAYS selected from CONTRIBUTIONS to the Edinburgh Review. By HeNry Rogers. Second Edition. 3 vols. fcp. $21 s$.

Reason and Faith, their Claims and Conflicts. By the same Author. New Edition, accompanied by several other Essays. Crown 8vo. 6s. $6 d$.

The Eclipse of Faith; or, a Visit to a Religious Sceptic. By the same Author. Twelfth Edition. Fcp. $5 s$.

Defence of the Eclipse of Faith, by its Author; a rejoinder to Dr. Newman's Reply. Third Edition. Fcp. $3 s .6 d$.

Selections from the Correspondence of R. E. H. Greyson. By the same Author. Third Edition. Crown 8vo. 7s. 6d.

occasional essays. By Chandos Wren Hoskyns, Author of 'Talpa, or the Chronicles of a Clay Farm,' \&c. 16mo. 5s. $6 d$.

CHIPS from a GERMAN WORKSHOP; being Essays on the Science of Religion, and on Mythology, Traditions, and Customs. By Max MÜLLER, M.A. Fellow of All Souls College, Oxford. 2 vols. 8vo. $21 s$.

An INTRODUCTION to MENTAL PHILOSOPHY, on the Inductive Method. By. J.D. Morel, M.A. LL.D. 8vo.12s.

Elements of Psychology, containing the Analysis of the Intellectual Powers. By the same Author. Post 8vo. 7s. 6d.

The SECRET of HEGEL: being the Hegelian System in Origin, Principle, Form, and Matter. By J. H. StIRLING. 2 vols. 8vo. 28 s.

The SENSES and the INTELIECT. By Alexander Bain, M.A. Professor of Logic in the University of Aberdeen. Third Edition. 8vo. 15s.

The EMotions and the WILL. By Alexander Baln, M.A. Professor of Logic in the University of Aberdeen. Second Edition. Svo.15s.

On the Study of Character, including an Estimate of Phrenology. By the same Author. 8vo. 9s.

TIME and SPACE: a Metaphysical Essay. By SHadworth H. HoDGSON. 8vo, price $15 s$. 
CHRISTIAN SCHOOLS and SCHOLARS; or, Sketches of Education from the Christian Era to the Council of Trent. By the Author of "The Three Chancellors,' \&c. 2 vols. 8vo. 30 s.

The WAY to REST: Results from a Life-search after Religious Truth. By R. VAUGHAN, D.D. Crown 8vo.7s.6d.

The PHILOSOPHY of NECESSITY; or, Natural Law as applicable to Mental, Moral, and Social Science. By Charles BrAY. Second Edition. 8vo. 9s.

The Education of the Feelings and Affections. By the same Author. Third Edition. 8vo. $3 s .6 d$.

On Force, its Mental and Moral Correlates. By the same Author. 8 vo. 5 s.

The FOLK-LORE of the NORTHERN COUNTIES of ENGLAND and the Borders. By William Hendersor. With an Appendix on Household Stories by the Rev. S. Baring-Gould, M.A. Post 8vo. 9s. $6 d$.

The SILVER STORE, Collected from Mediæval Christian and Jewish Mines. By S. Baring-Gould, M.A. Crown 8vo. $6 s$.

Astronomy, Meteorology, Popular Geography, \&c.

OUTLINES of ASTRONOMY. By Sir J. F. W. Herschel, Bart. M.A. Ninth Edition, revised; with Plates and Woodcuts. 8vo.18s.

SATURN and its SYSTEM. By RIChaRd A. Proctor, B.A. late Scholar of St John's Coll. Camb. 8vo. with 14 Plates, 14s.

Handbook of the Stars. By the same Author. With 3 Maps. Square fcp. 5s.

CELESTIAL OBJECTS for COMMON TELESCOPES. By the Rev. T. W. WEBB, M.A. F.R.A.S. Revised Edition, with a large Map of the Moon, a New Plate, and several Woodcuts. 16mo. 7s. $6 d$.

DOVE'S LAW of STORMS, considered in connection with the Ordinary Movements of the Atmosphere. Translated by R. H.ScotT, M.A.T.C.D. 8vo. 10s. $6 d$.

PHYSICAL GEOGRAPHY for SCHOOLS and GENERAL READERS. By M. F. MAURY, LL.D. Fep. with 2 Charts, $2 s$. $6 d$.

A TREATISE on the ACTION of VIS INERTIE in the OCEAN; with Remarks on the Abstract Nature of the Forces of Vis Inertiæ 'and Gravitation, and a New Theory of the Tides. By Wriliam LeightoN JoRDAN, F.R.G.S. With 12 Charts and Diagrams. 8vo. 14s.

M'CULLOCH'S DICTIONARY, Geographical, Statistical, and Historical, of the various Countries, Places, and Principal Natural Objects in the World. New Edition, with the Statistical Information brought up to the latest returus by F. MARTIN. 4 vols. 8vo. with coloured Maps, \&4 $4 s$.

A GENERAL DICTIONARY of GEOGRAPHY, Descriptive, Physical, Statistical, and Historical : forming a complete Gazetteer of the World. By A. KEITI JoHnston, LL.D. F.R G.S. Revised to July 1967. 8vo.31s. $6 d$.

A MANUAL of GEOGRAPHY, Physical, Industrial, and Political. By W. HUGHes, F.R.G.S. With 6 Maps. Fcp.78. $6 d$. 
The STATES of the RIVER PLATE: their Industries and Commerce. By Wilfrid LathaM, Buenos Ayres. Second Edition, revised. 8vo.12s.

HAWAII; the Past, Present, and Future of its Island-Kingdom : an Historical Account of the Saudwich Islands. By MANLEY HOPKINS, Second Edition, with Portrait, Map, \&c. Post 8vo. 10s. 6d.

MAONDER'S TREASURY of GEOGRAPHY, Physical, Historical, Descriptive, and Political. Edited by W. HUGHEs, F.R.G.S. With 7 Maps and 16 Plates. Fep. 10s. $6 d$.

\section{Natural History and Popular Science.}

ELEMENTARY TREATISE on PHYSICS, Experimental and Applied. Translated and edited from GANoT's Eléments de Physique (with the Author's sanction) by E. ATKINson, Ph. D. F.C.S. New Edition, revised and enlarged; with a Coloured Plate and 620 Woodcuts. Post 8vo. 15s.

The ELEMENTS of PHYSICS or NATURAL PHILOSOPHY. By NeIL ARNotT, M.D. F.R.S. Physician Extraordinary to the Queen. Sixth Edition, rewritten and completed. Two Parts, 8vo. 21 s.

SOUND : a Course of Eight Lectures delivered at the Royal Institution of Great Bitain. By JoHN TYNDALI, LL.D. F.R.S. Crown 8vo. with Portrait of M. Chladni and 169 Woodcuts, price $9 s$.

HEAT CONSIDERED as a MODE of MOTION. By Professor JoHN TYNDALL, LL.D. F.R.S. Third Edition. Crown 8vo. with Woodcuts, 108. $6 d$.

LIGHT: Its Influence on Life and Health. By Forbes WinsLow, M.D. D.C.L. Oxon. (Hon.). Fep. 8vo. 6s.

An ESSAY on DEW, and several Appearances connected with it. By W. C. Wells. Edited, with Annotations, by L. P. Casella, F.R.A.S. and an Appendix by R. STRACHAN, F.M.S. 8vo. $5 s$.

ROCKS CLASSIFIED and DESCRIBED. By BERNHARD VON CotTA. An English Edition, by P. H. LAwrence (with English, German, and French Synonymes), revised by the Author. Post 8vo. 14s.

A TREATISE on EIECTRICITY, in Theory and Practice. By A. DE LA RIVE, Prof. in the Academy of Geneva. Translated by C. V. WALKER, F.R.S. 3 vols. 8 vo. with Woodcuts, $2313 s$.

The CORRELATION of PHYSICAL FORCES. By W. R. Grove, Q.C. V.P.R.S. Fifth Edition, revised, and followed by a Discourse on Continuity. 8vo. 10s. $6 d$. The Discourse on Continuity, separately, $2 s .6 d$.

MANUAL of GEOLOGY. By S. HAUGHTON, M.D. F.R.S. Revised Edition, with 66 Woodcuts. Fep. 7s. $6 d$.

A GUIDE to GEOLOGY. By J. Phillips, M.A. Professor of Geology in the University of Oxford. Fifth Edition, with Plates. Fep. 4s.

A GLOSSARY of MINERALOGY. By H. W. BRISTOW, F.G.S. of the Geological Survey of Great Britain. With 486 Figures. Crown 8vo. 6s.

VAN DER HOEVEN'S HANDBOOK of ZOOLOGY. Translated from the Second Dutch Edition by the Rev. W. ClarK, M.D. F.R.S. 2 vols. 8 vo. with 24 Plates of Figures, 60s. 
Professor OWEN'S LECTURES on the COMPARATIVE ANATOMY and Physiology of the Invertebrate Animals. Second Edition, with 235 Woodcuts. Svo. $21 s$.

The COMPARATIVE ANATOMY and PHYSIOLOGY of the VERTEbrate Animals. By RICHARD OWEN, F.R.S. D.C.L. 3 vols. 8 vo. with above 1,200 Woodcuts. VoLs. I. and II. price 21s. each. VoL. III. just ready.

The FIRST MAN and HIS PLACE in CREATION, considered on the Principles of Common 'S $\mathrm{S}$ nse from a Christian Point of View, By GEORge Moore, M.D. Post 8vo. 8s. 6d.

The PRIMITIVE INHABITANTS of SCANDINAVIA: an Essay on Comparative Ethnography, and a Contribution to the History of the Development of Mankind. Containing a description of the Implements, Dwellings, Tombs, and Mode of Jiving of the Savages in the North of Europe during the Stone Age. By Sver NILsson. Translated from the Third Edition: with an Introduction by Sir J. LUBвоck. With 16 Plates of Figures and 3 Woodcuts. 8vo. $18 s$.

The LAKE DWELLINGS of SWITZERLAND and other parts of Europe. By Dr. F. KelI. Translated and arranged by J. E. LEE, F.S.A. F.G.S. With Woodcuts and nearly 100 Plates of Figures. Royal 8vo.31s.6d.

BIBLE ANIMALs; being an Account of the various Birds, Beasts, Fishes, and other Animals mentioned in the Holy Scriptures. By the Rev. J. G. WooD, M.A. F.L.S. Copiously illustrated with Original Designs, made under the Author's superintendence and engraveil on Wood. In course of publication monthly, to be completed in 20 Parts, price $1 s$. cach, forming One Volume, uniform with 'Homes without Hands.'

HOMES WITHOUT HANDS : a Description of the Habitations of Animals, classed according to their Principle of Construction. By Rev. J. G. WooD, M.A. F.L.S. With about 140 Vignettes on Wood ( 20 full size of page). Second Edition. 8vo. 21s.

MANUAL of CORALS and SEA JELLIES. By J. R. Greene, B.A. Edited by Joseph A. Galbraith, M.A. and Samuel HaUghton, M.D. Fcp. with 39 Woodcuts, $5 s$.

Manual of Sponges and Animalculæ; with a General Introduction on the Principles of Zoology. By the same Author and Editors. Fcp. with 16 Woodcuts, $2 s$.

Mannal of the Metalloids. By J. ApJorn, M.D. F.R.S. and the same Editors. Revised Edition. Fep. with 38 Woodcuts, $7 s .6 d$.

The HARMONIES of NATURE and UNITY of CREATION. By Dr. GEORGE HARTWIG. 8vo. with numerous Illustrations, 18s.

The Sea and its Living Wonders. By the same Author. Third (English) Edition. 8vo. with many Illustrations, $21 s$.

The Tropical World. By the same Author. With 8 Chromoxylographs and 172 Woodcuts. 8vo. 21s.

The POLAR WORLD; a Popular Account of Nature and Man in the Arctic and Antarctic Regions By the same Author. 8vo. with numerous Illustrations.

[Nearly ready.

A FAMILIAR HISTORY of BIRDS, By E. StaNLEY, D.D. F.R.S. late Lord Bishop of Norwich. Seventh Edition, with Woodeuts. Fcp. 3s.6d. 
CEYloN. By Sir J. Emerson Tenvent, K.C.S. LL.D. Fifth Edition; with Maps, \&c. and 90 Wood Engravings, 2 vols. 8 vo. $£ 210 s$.

The Wild Elephant, its Structure and Habits, with the Method of Taking and Training it in Ceylon. By the same Author. Fep. 8vo. with 22 Woodcuts, $3 s .6 d$.

KIRBY and SPENCE'S INTRODUCTION to ENTOMOLOGY, or Elements of the Natural History of Insects. 7th Edition. Crown 8vo. 5s.

MAUNDER'S TREASURY of NATURAL HISTORY, or Popular Dictionary of Zoology. Revised and corrected by T. S. CoBbold, M.D. Fep. with 900 Woodcuts. 10 s.

The TREASURY of BOTANY, or Popular Dictionary of the Vegetable Kingdom ; including a Glossary of Botanical Terms. Edited by J.LINDLEY, F.R.S. and T. MooRE, F.L.S. assisted by eminent Contributors. Yp. 1,274, with 274 Woodcuts and 20 Steel I'lates. 2 Parts, fep. 20 s.

The ELEMENTS of BOTANY for FAMILIES and SCHOOLS. Tenth Edition, revised by Tromas Moore, F.L.S. Fep. with 154 Woodcuts, $2 s, 6 d$.

The ROSE AMaTeUR's GUIDE. By Thomas Rrvers. Twelfth Edition. Fcp. 4s. :

The BRITISH FLORA; comprising the Phænogamous or Flowering Plants and the Ferns. By Sir W.J. HookER, K.H. and G. A. WALKERARNotT, LL.D. $12 \mathrm{mo}$. with 12 Plates, 14s. or coloured, $21 s$.

LOUDON'S ENCYCLOP FDIA of PLANTS; comprising the Specific Character, Description, Culture, History, \&c. of all the Plants found in Great Britain. With upwards of 12,000 Woodeuts. 8vo. $42 s$.

Loudon's Encyclopædia of Trees and Shrubs; containing the Hardy Trees and Shrubs of Great Britain scientifically and popularly described. With 2,000 Woodcuts. 8 vo. 50 s.

MAUNDER'S SCIENTIFIC and LITERARY TREASURY. New Edition, thoroughly revised and in great part re-written, with above 1,000 new Articles, by J. Y. Johrson, Corr. M.Z.S. Fep. 10s. $6 d$.

A DICTIONARY of SCIENCE, LITERATURE, and ART. Fourth Edition, re-edited by W.T. BRANDE (the Author), and GEORGE W. Cox. M.A. assisted by contributors of eminent Scientific and Literary Acquirements. 3 vols. medium 8 vo. price $63 s$, cloth.

\section{Chemistry, Medicine, Surgery, and the Allied Sciences.}

A DICTIONARY of CHEMISTRY and the Allied Branches of other Sciences: founded on that of the late Dr. Ure. Bv HENRY WATts, F.C.S. assisted by eminent Contributors. VoL. I. 31s. $6 \pi$. VoL. II. 26s. VoL. III. $31 s .6 d$. Vol. IV. 24s, and VoL. V. 30s. Complete in 5 vols. medium 8vo. \&73. 
The CHORALE BOOK for ENGLAND: the Hymns translated by Miss C. WinkworTH; the tunes arranged by Prof. W. S. BENNETT and OtTo GoldschmidT. Fcp.4to.12s.6d.

Congregational Edition. Fcp. $2 s$.

SACRED MUSIC for FAMILY USE; a Selection of Pieces for One, Two, or more Voices, from the best Composers, Foreign and English. Edited by JoHN HULLAH. 1 vol. music folio, price $21 s$.

The NEW TESTAMENT, illustrated with Wood Engravings after the Early Masters, chiefly of the Italian School. Crown 4to.63s. cloth, gilt top or $£ 5$ 5s. elegantly bound in morocco.

IYRA GERMANICA ; the Christian Year. Translated by CATHerine WINKWORTH; with 125, Illustrations on Wood drawn by J. LEIGHTON, F.S.A. 4to. $21 s$.

IYRA GERMANICA; the Christian Life. Translated by Catherine WINKWORTH: with about 200 Woodcut Illustrations by J. LEIGHTON, F.S.A. and other Artists. 4to. $21 s$.

The LIFE of MAN SYMBOLISED by the MONTHS of the YEAR. Text selected by R. PIGor; Illustrations on Wood from Original Designs by J. LEIGHTON, F.S.A. 4 to. $42 s$.

CATS' and FARLIE'S MORAL EMBLEMS ; with Aphorisms, Adages, and Proverbs of all Nations. 121 Illustrations on Wood by J. LEIGHTON, F.S.A. Text selected by R. Prgot. Imperial 8vo.31s. $6 d$.

SHAKSPEARE'S SENTIMENTS and SIMILES, printed in Black and Gold, and Illuminated in the Missal Style by HENRY NOEL HUMPHREYs. Square post 8vo. $21 s$.

SACRED and LEGENDARY ART. By Mrs. JAMESon.

Iegends of the Saints and Martyrs. Fifth Edition, with 19 Etchings and 187 Woodents. 2 vols, square crown 8vo. 31s. $6 d$.

Iegends of the Monastic Orders. Third Edition, with 11 Etchings and 88 Woodcuts. 1 vol. square crown 8 vo. $21 s$.

Iegends of the Madonna. Third Edition, with 27 Etchings and 165 Woodcuts. 1 vol. square crown 8 vo. 21 s.

The History of Our Lord, with that of his Types and Precursors. Completed by Lady Eastrake. Revised Edition, with 31 Etchings and 281 Woodcuts. 2 vols. square crown 8 vo. $42 s$.

\section{Arts, Manufactures, \&c.}

DRAWING from NATURE. By George Barnard, Professor of Drawing at Rugby School. With 18 Lithographic Plates, and 108 Wood Engravings. Imperial 8vo. price 25s. Or in Three Parts, royal 8vo. Part I. Trees and Foliage, 7s.6d. Part II. Foreground Studies, 7s. 6d. Part III. Tour in Switzerland and the Pyrenees, $7 s .6 d$.

GWILT'S ENCYCLOPEDIA of ARCHITECTURE, with above 1,100 Engravings on Wood. Fifth Edition, revised and enlarged by WratT PAPWORTH. Additionally illustrated with nearly 400 Wood Engravings by O. Jewitt, and more than 100 other new Woodeuts. 8vo. 52s. $6 d$. 
TUSCAN SCULPTORS, their Lives, Works, and Times. With 45 Etchings and 28 Woodcuts from Original Drawings and Photographs. By Charles C. Perkins. 2 vols. imperial 8 vo. 633.

ORIGINAL DESIGNS for WOOD-CARVING, with PRACTICAL INstructio: $s$ in the Art. By A. F. B. With 20 Plates of lllustrations engraved on Wood. 4tn. $18 s$.

HINTS On HOUSEHOLD TASTE in FURNITURE and DECORATION. by Charles L. Eastiake, Architect. With numerous Illustrations eligraved on Wood.

[Nearly ready.

The ENGINEER'S HANDBOOK; explaining the Principles which should guide the Young Engineer in the Construction of Machinery. By C. S. Lowndes. Post 8 vo. 5s.

The ELEMENTS of MECHANISM. By T. M. Goodeve, M.A. Professor of Mechauics at the R. M. Acad. Woolwich. Second Edition, with 217 Woodcuts. Post 8vo. 6s. 6d.

ORE'S DICTIONARY of ARTS, MANUFACTURES, and MINES. Sixth Edition, chilfly rewritten and preatly enlarged by RoBEnT HUNT, F.R.S. assisted by numerous Contributors eminent in Science and the Arts, and familiar with Mannfartures. With above 2,000 Woodcuts. 3 vols. medium 8vo. price $2414 s .6 d$.

ENCYCLOP EDDIA of CIVIL ENGINEERING, Historical, Theoretical, and Practical. By E. Cresx, C.E. With above 3,000 Woodcuts. 8vo. 42s.

TREATISE on MILLS and MILLWORK. By W. FaIrbairn, C.E. Second Edition, with 18 Plates and 322 Woodcuts. 2 vols. 8vo. 32s.

Useful Information for Engineers. By the same Author. Frast, SeCOND, and THIRD Series, with many Plates and Woodcuts. 3 vols. crown 8 vu. 10 s. $6 d$. each.

The Application of Cast and Wrought Iron to Building Purposes. By the same Author. Third Edition, with 6 Plates and 118 Woodcuts. 8vo.16s. IRON SHIP BUILDING, its History and Progress, as comprised in a Series of Experimental Researches. By the same Author. With 4 Plates and 130 Woodcuts. svo. $18 s$.

A TREATISE on the STEAM ENGINE, in its various Applications to Mines, Mills, Steam Navigation, Railways and Agriculture. By J. BouRNE, C.E. Eighth Edition : with Portrait, 37 Plates, and 546 Woodcuts. 4to. 42 s. Catechism of the Steam Engine, in its various Applications to Miues, Mills, Steam Navigation, Railways, and Agriculture. By the same Author. With 199 Woodcuts. Fcp. $6 s$.

Handbook of the Steam Engine. By the same Author, forming a KEY to the Catechism of the Steam Engine, with 67 Wondcuts. Fcp. 9s.

A TREATISE on the SCREW PROPELLER, SCREW VESSELS, and Screw Engines, as adapted for purposes of Peace and War; with Notices of other Methods of Propulsion, Tables of the Dimensions and Performance of Screw Steamers, and detailed S recifications of ships and Engines, By J. BourNe, C.E. Third Edition, with 54 Plates and 287 Wuodcuts. 4to, 63s.

EXAMPLES of MODERN STEAM, AIR, and GAS ENGINES of the most Approved Types, as employed for Puinping, lor Driving Machinery, for Locomotion, and tor Akriculture, minntely and iractically described. Illustrated by Working Drawings, and e $u b$ odying a Critical Account of all Projects of Recent Improvement in Furnaces, Boilers, and Engines. By the same Author. In course of publication monthly, to be completed in 24 Parts, price 2s. $6 d$. each, formiug One volume 4to. with about 50 Plates and 100 Woodcuts. 
A HISTORY of the MACHINE-WROUGHT HOSIERY and LACE Manufactures. By WiLliax Felkin, F.L.S. F.S.S. Royal 8vo. $21 s$.

MANUAL of PRACTICAL ASSAYING, for the use of Metallurgists, Captains of Mines, and Assayers in general. By Jorn MrTCHELL, T.C.S. Second Edition, with 360 Woodcuts. 8vo. 21 s.

The ART of PERFUMERY; the History and Theory of Odours, and the Methods of Extracting the Aromas of Plants. By Dr. Presse, F.C.S. Third Edition, with 53 Woodcuts. Crown 8vo. 10s. $6 d$.

Chemical, Natural, and Physical Magic, for Juveniles during the Holidays. By the same Author. Third Edition, with 38 Woodcuts. Fcp. $6 s$.

IOUDON'S ENCYCLOPIEDIA of AGRICULTURE: comprising the Laying-out, Improvement, and Management of Landed Property, and the Cultivation and Economy of the Productions of $\Lambda$ griculture. With 1,100 Woodcuts. 8vo. 31s. $6 d$.

Ioudon's Encylopædia of Gardening: comprising the Theory and Practice of Horticulture, Floriculture, Arboriculture, and Landscape Gardening. With 1,000 Woodcuts. 8vo. 31s. $6 d$.

Ioudon's Encyclopædia of Cottage, Farm, and Villa Architecture and Furniture. With more than 2,000 Woodcuts. 8vo. 42s.

BAYLDON'S ART Of VALUING RENTS and TILLAGES, and Claims of Tenants apon Quitting Farmis, both at Michaelmas and Lady-Day. Eighth Edition, revised by J. C. MorTon. 8vo. 10s. $6 d$.

\section{Religious and Moral Works.}

An EXPOSITION of the 39 ARTICLES, Historical and Doctrinal. By E. HAROLD BRowne, D.D. Lord Bishop of Ely. Seventh Edit. Svo. 16s.

The ACTS of the APOSTLES; with a Commentary, and Practical and Devotional Suggestions for Readers and Students of the English Bible. By the Rev. F. C. Coor, M.A. Canon of Exeter, \&c. New Edition. 8vo. 12s. $6 \dot{d}$.

The IIFE and EPISTLES of ST. PAUL. By W. J. ConyBEare, M.A. late Fellow of Trin. Coll.Cantab. and the Very Rer.J. S. Howson, D.D. Dean of Chester.

LIBRARY EDITION, with all the Original Illustrations, Maps, Landscapes on Stcel, Woodcuts, \&c. 2 vols. 4 to. $48 s$.

INTERM EDIATE EDITION, with a Selection of Maps, Plates, and Woodcuts. 2 vols. square crown 8 vo. 31 s. $6 d$.

PEOPLE's EDITION, revised and condensed, with 46 Illustrations and Maps. 2 vols. crown 8 vo. 12 s.

The VOYAGE and SHIPWRECK of ST. PAUL; with Dissertations on the Life and Writings of St. Luke ard the Ships and Navigation of the Ancients. By J AMES Surth, F.R.S. Third Edition. Crown 8vo. 1us. 6d.

EVIDENCE of the TRUTH of the CHRISTIAN RELIGION derived from the Literal Fulfilment of Prophecy. By ALEXANDER KEITH, D.D. 37th Edition, with bumerous Plates, in square 8vo. 12s. $6 \mathrm{~d}$.; ;ilso the 39th Edition, in post 8vo. with 5 Plates, 6 s.

The HISTORY and DESTINY of the WORLD and of the CHURCH. according to Scripture. By the same Author. Square 8vo. with 40 Illustrations, $10 s$. 
A CRITICAL and GRAMMATICAL COMMENTARY On ST. PAUL'S Epistles, By C.J. ELLICotT, D.D. Lord Bishop of Gloucester and Bristol. 8vo. Galatians, Third Edition, $8 s .6 d$.

Ephesians, Fourth Edition, 8s. $6 d$. Pastoral Epistles, Third Edition, 10s. 6d.

Philippians, Colossians, and Philemon, Third Edition, 10s. $6 d$. Thessalonians, Third Edition, 7s. $6 d$.

Historical Lectures on the Life of our Lord Jesus Christ: being the Hulsean Lectures for 1859. By the same Author. Fourth Edition. 8vo. price 10s. $6 d$.

An INTRODUCTION to the STUDY of the NEW TESTAMENT, Critical, Eregetical, and Theological. By the Rev. S. DAvidson, D.D. LL.D. 2 vols. 8 vo. $30 s$.

Rev. T. H. HORNE'S INTRODUCIION to the CRITICAL STUDY and Knowledge of the Holy Scriptures. Eleventh Edition, corrected and extended under careful Editorial revision. With 4 Maps and 22 Woodcuts and Facsimiles. 4 vols. 8 vo. $£ 313 s .6 d$.

Rev. T. H. Horne's Compendious Introduction to the Study of the Bible, being an Analysis of the larger work by the same Author. Re-edited by the Rev. JoHN AYRE, M.A. With Maps, \&c. Post 8yo. 9s.

EWALD'S HISTORY of ISRAEL to the DEATH of MOSES. Translated from the German. Edit d, with a Preface, by Russell Martineat, M.A. Prof. of Hebrew in Manchester New Coll. Loudon. 8vo. 18s.

The TREASURY of BIBLE KNOWLEDGE; being a Dictionary of the Books, Persons, Places, Events, and other matters of which mention is made in Holy Scripture. By Rev. J. AYRE, M.A. With Maps, 16 Plates, and numerous Woodeuts. Fcp. 10 s. $6 d$.

The LIFE and REIGN of DAVID KING of ISRAEL. By GEORGE SMITH, LLD. F.A.S. Crown 8vo. 7 s. $6 d$.

Tho GREEK TESTAIENT; with Notes, Grammatical and Exegetical. By the Rev. W. Weisster, M.A. and the Rev. W. F. Wilikinson, M.A. 2 vols. 8 vo. $£ 24 s$.

Vor. I. the Gospels and Acts, 20 s.

Vor. II. the Epistles and Apocalypse, 24s.

EVERY-DAY SCRIPTURE DIFFICULTIES explained and illustrated. By J. E. Prescotr, M.A. Vor. I. Matthew and Mark; Vor. II. Luke and John. 2 vols, 8 vo. $9 s$. each.

The PENTATEUCH and BOOK of JOSHUA CRITICALIY EXAMINED. By the Right Rev. J. W. Colenso, D.D. Lord Bishop of Natal. People's Édition, in 1 vol. crown 8vo. $6 s$. or in 5 Parts, $1 s$, each.

The CHURCH and the WORLD: Essays on Questions of the Day. By Various Writers. Edited by the Rev. Orbr Surpler. M.A. First Szries, Third Edition, 8vo. 15 s. Second Series, 8vo. 15s. Third Series, Svo. 15s. 
TRACTS for the DAY; a Series of Essars on Theological Suhjects. By various Authors. Edited by the Rev. ORBY SHIPLegr, M.A. I. Priestly Absolution Scriptural, 9d. II. Purgatory, 9d. I11. The Seven Sacraments, 1s. 6d. IV. Miracles and Prayer. fid. V. The Real Presence, 1s. 3d. VI. Cusuistry, 1s. VII. Unction of the Sick, 9d. VIII. The Rule of Worship, 9d. IX. Popular Rationalism, $9 d$.

The Formation of christendom. Part I. By T. W. Alimes, 8vo.12s.

CHRISTENDOM'S DIVISIONS, PART I., a Philosophical Sketch of the Divisions of the Christian Family in East and West. By EDMUND S. FFoulKes. Post 8vo. price 7s. $6 d$.

Christendom's Divisions, Part II. Greeks and Latins, being a History of their Dissensions and Overtures for Peace down to the Reformation. By the same Author. Post 8vo.15s.

The HIDDEN WISDOM of CHRIST and the KEY of KNOWLEDGE; or, History of the Apocrypha. By ERNEST DE BuNsEN. 2 vols. 8vo. 28s.

The KEYS of ST. PETER; or, the House of Rechab, connected with the History of Symbolism and Idolatry. By the same Author. 8vo.14s.

ESSAYS on RELIGION and IITERATURE. Edited by Archbishop Manning, D.D. 8vo. 10s.6d. Second Series, price $14 s$.

The TEMPORAI MISSION of the HOLY GHOST; or, Reason and Revelation. By Archbishop Manning, D.D. Second Edit. Cr. 8vo. 8s.6d.

ENGIAND and CHRISTENDOM. By the same Author. Post 8 vo. price $10 s .6 d$.

ESSAYS and REVIEWS. By the Rev. W. Temple, D.D. the Rev. R. Willilams, B.D. the Rev. B. Poweli, M.A. the Rev. H. B. Wilson, B.D. C. W. Goodwin, M.A. the Rev. M. Patrison, B.D. and the Rev. B. Jowet, M.A. Twelfth Edition. Fep. 8vo. 5s.

The CATHOLIC DOCTRINE of the ATONEMENT: an Historical Inquiry into its Development in the Cburch. By H. N. OxenHaM, M.A. 8v0.8s. $6 d$.

PASSING THOdGHTS on RELIGION. By Elizabeth M. Sewell, Author of 'Amy Herbert.' New Edition. Fcp. 8vo. 5s.

Self-Examination before Confirmation. By the same Author. $32 \mathrm{mo}$. price $1 s .6 d$.

Readings for a Month Preparatory to Confirmation, from Writers of the Early and English Church. By the same Autbor. Fep. 4 s.

Readings for Every Day in Lent, compiled from the Writings of Bishop Jeremy TAYLor. By the same Author. Fcp. $5 s$.

Preparation for the Holy Communion; the Devotions chiefly from the works of JEREMY TAYLOR. By the same. 32mo. $3 s$.

PRINCIPLES of EDUCATION Drawn from Nature and Revelation, and applied to Female Education in the Upper Classes. By the Author of 'Amy Herbert.' 2 vols. fep. $12 s .6 d$. 
The WIFE'S MANUAL; or, Prayers, Thoughts, and Songs on Several Occasions of a Matron's Life. By the Rev. W. Calvert, M.A. Crown $8 v 0$. price $10 s .6 d$.

'SPIRITUAL SONGS' for the SUNDAYS and HOLIDAYS throughout the Year. By J.S. B. Monsell, LL.D. Vicar of Egham and Rural Dean. Sixth Thousand. Fep. 4s. 6d.

The Beatitudes: Abasement before God; Sorrow for Sin ; Meekness of Spirit: Desire for Holiness ; Gentleness; Purity of Heart; the Peacemakers ; Sufferings for Christ. By the same. Third Edition. Fcp. 3s. 6d.

His PRESENCE-not his MEMORY, 1855. By the same Author, in Memory of his Son. Fifth Edition. 16mo. $1 s$.

IYRA DOMESTICA; Christian Songs for Domestic Edification. Translated from the Psaltery and Harp of C. J. P. SPITTA, and from other sources, by Richard Massie. First and Second Series, fep. 4s.6d. each.

IYRA SACRA; Hymns, Ancient and Modern, Odes and Fragments of Sacred Poetry. Edited by the Rev. B. W. SAvILE, M.A. Third Edition, enlarged and improved. Fcp. 5s.

IYRA GERMANICA, translated from the German by Miss C. WINKWORTH. FIRST SERIES, Hymns for the Sundays and Chief Festivals : SeCOND Series, the Christian Life. Fcp. 3s. 6d. each SerIes.

IYRA EUCHARISTICA; Hymns and Verses on the Holy Communion, Ancient and Modern : with other Poems. Edited by the Rev. ORBY SHIPLEY, M.A. Second Edition. Fcp. 7s. $6 d$.

Iyra Messianica; Hymns and Verses on the Life of Christ, Ancient and Modern; with other Poems. By the same Editor. Second Edition, altered and enlarged. Fcp. $7 s .6 d$.

Lyra Mystica; Hymns and Verses on Sacred Subjects, Ancient and Modern. By the same Editor. Fcp. 7s. 6d.

ENDEAVOURS after the CHRISTIAN IIFE: Discourses. By James Martineav. Fourth and clieaper Edition, carefully revised; the Two Series complete in One Volume. Post 8vo. 7s. $6 d$.

WHATELY'S Introductory Lessons on the Christian Evidences. $18 \mathrm{mo} .6 d$.

INTRODUCTORY LESSONS on the HISTORY of RELIGIOUS Worship; being a Sequel to the 'Lessons on Christian Evidences.' BJ RICHARD WHATELY, D.D. New Edition. 18mo. $2 s .6 d$.

MOSHEIM'S ECCLESIASTICAI HISTORY. MURDOCK and SOAMEs's Translation and Notes, re-edited by the Rev. W. StubBs, M.A. 3 vols. 8 vo. 45s.

BISHOP JEREMY TAYLOR'S ENTIRE WORKS. With Life by BisHop HEBEr. Revised and corrected by the Rev. C. P. EDEN, 10 vols. price £5 $5 s$.

\section{Travels, Voyages, \&c.}

The NORTH-WEST PENINSULA of ICELAND; being the Journal of a Tour in Iceland in the Summer of 1862. By C. W. SHEPHERD, M.A. F.Z.S. With a Map and Two Illustrations. Fcy. 8vo. 7s.6d. 
PICTURES in TYROL and Elsewhere. From a Family Sketch-Book: By the-Authoress of 'A Voyage en Zigzag;' \&c. Small 4to. with numerous Illustrations, $21 s$.

HOW WE SPENT the SUMMER; or, a Voyage en Zigzag in Switzerland and Tyrol with some Members of the ALPINE CLUB. From the SketchBook of one of the Party. In oblong 4to. with 300 Illustrations, 15s.

BEATEN TRACKS; or, Pen and Pencil Sketches in Italy. 13y the Authoress of 'A Voyage en Zigzag.' With 42 Plates, containing about 200 Sketches from Drawings made on the Spot. 8vo. 16s.

MAP of the CEAIN of MONT BLANC, from an actual Survey in 1863-1864. By A. AdAMs-REILLT, F.R.G.S. M.A.C. Published under the Authority of the Alpine Club. In Chromolithography on extra stout drawing-paper 28in. $\times 17 \mathrm{in}$. price $10 \mathrm{~s}$. or mounted on canvas in a folding case, $12 s .6 d$.

HISTORY of DISCOVERY in our AOSTRALASIAN COLONIES, A ustralia, Tasmania, and New Zealand, from the Earliest Date to the Present Day. By WilliaM HowitT. 2 vols, 8vo. with 3 Maps, 20 s.

The CAPITAL of the TYCOON; a Narrative of a Three Years' Residence in Japan. By Sir RUTHERFORD ALCOCK, K.C.B. 2 vols. 8vo. with numerous Illustrations, $42 s$.

FLORENCE, the NEW CAPITAL of ITALY. By C. R. WELD. With several Woodcuts from Drawings by the Author. Post 8ro. 12s. 6d.

The DOLOMITE MOUNTAINS; Excursions through Tyrol, Carinthia, Carniola, and Friuli, 1861-1863. By J. GrLBERT and G. C. CHURCHILL, F.R.G.S. With numerous Illustrations. Square crown Svo. $21 s$.

A LADY'S TOUR ROUND MONTE ROSA; including Visits to the Italian Valleys. With Map and Illustrations. Post 8vo. 14s.

GUIDE to the PYRENEES, for the use of Mountaineers. By CHARLES PACKe. $2 d$ Edition, with Map and Illnstrations. Cr. 8vo. 7s.6d.

The ALPINE GUIDE. : By JoHn BaLL, M.R.I.A. late President of the Alpine Club. Post 8vo. with Maps and other Illustrations.

Guide to the Eastern Alps, nearly ready.

Guide to the Western Alps, including Mont Blane, Monte Rosa Zermatt, \&c. 7s. $6 d$.

Guide to the Oberland and all Switzerland, excepting the Neighbourhood of Monte Rosa and the Great St. Bernard; with Lombardy and the adjoining portion of Tyrol. $7 s .6 d$.

NARRATIVES of SHIPWRECKS of the ROYAL NAVY between 1793 and 1857, compiled from Official Documents in the Admiralty by W. O.S GILlY; with a Preface by W. S. GILLY, D.D. Third Edition. Fep. 5s.

TRAVELS in ABYSSINIA and the GALLA COUNTRY; with an Account of a Mission to Ras Ali in 1849. From the MSS. of the late WALTER CHICHELE PLOWDEN, Her Britannic Majesty's Consul in Abyssinia. Edited by his Brother Trevor Chichele Plowden. With Two Maps. 8vo. 18s.

The ARCH of TITUS and the SPOILS of the TEMPLE; an His. torical and Critical Lecture, with Authentic Illustrations. By WiLliam KNIGHT, M.A. With 10 Woodcuts from Ancient Remains. 4to. 10s. . 
A WEER at the LAND'S END. By J. T. BLIGHT; assisted by E. H. RODd, R. Q. CodCH, and J. RALFs. With Map and 96 Woodcuts. Fcp. price $6 s .6 d$.

CURIOSITIES of IONDON ; exhibiting the most Rare and Remarkable Objects of Intere $t$ in the Metropolis; - with nearly Sixty Years' Personal Recollections. By Jorrs TimBs, F.S.A. New Edition, corrected and enlarged. 8vo. with Portrait, $21 s$.

VISITS to REMARKABLE PLACES : Old Halls, Battle-Fields, and Scenes Illustrative of Striking Passages in English History and Poetry. By WilliaM HowITT. 2 vols. square crown 8vo. with Woodcuts, $25 s$.

The RURAL LIFE of ENGLAND. By the same Anthor. With Woodcuts by Bewick and Williams. Medium 8vo.12s. $6 d$.

The ENGIIShMaN in INDIA. By Charles Raikes, Esq. C.S.I. formerly Commissioner of Lahore. Post 8vo.7s. $6 d$.

INDIAN POIITY : a View of the System of Administration in India. By GEORGE CHESNEY, Accomptant-General to the Government of India, Public Works Department; Fellow of the University of Calcutta. With a $M_{A P}$ shewing the latest Political Divisions of India. 8v0. 21s.

The STORY of MAIRWARA; or, Our Rule in India. Portrait. Crown 8vo. 3s. $6 d$.

The IRISH in AMERICA. By John Francis Maguire, M.P. for Cork. Post 8vo. 12s. $6 d$.

\section{Works of Fiction.}

The WARDEN: a Novel. By Anthonx Trollope. Crown 8vo. 2s. 6d. Barchester Towers: a Sequel to 'The Warden.' By the same Author. Crowu 8vo. 3s. 6d.

SPRINGDALE ABBEY : Extracts from the Letters of an ENGLisH PREACHer. 8vio. 12s.

STORIES and TALES by Elizabeth M. Sewell, Anthor of 'Amy Herbert,' uniform Edition, each Tale or Story complete in a single Volume. AMY HERBERT, $2 s .6 d$. GERTRUDE, 2s. $6 d$.

EARL'S DAUGHTER, $2 s .6 d$. EXPERIENCE OF LIFE, $2 s, 6 d$. CLEVE HALL, 3s. $6 d$.

IvORs, $3 s .6 d$.

KATHARINE AshTON, 3s. $6 d$. margaret Percivat, $5 s$. LANRTON PARSONAGE, 4s. 6d. URSULA, $4 s .6 d$.

A Glimpse of the World. By the Author of 'Amy Herbert.' Fcp. 7s.6d. The Journal of a Home Life. By the same Author. Post 8vo. 9s.6d. After Life; a Sequel to 'The Journal of a Home Life.' By the same Author. l'ost 8vo. 10s.6d.

BECKER'S GALLUS; or, Roman Scenes of the Time of Augustus : with Notes and Excursuses. New Edition. Post 8vo. 7s. 6d.

BECKER'S CHARICLES; a Tale illustrative of Private Life among the Ancient Greeks : with Notes and Excursuses. New Edition. Post 8vo.7s.6d. 
NOVELS and TALES by G.J. Whyte Melville:The Gladiators: A Tale of Rome and Judæa. Crown 8vo. 5s. Digby Grand, an Autobiography. Crown 8vo. 5s. Kate Coventry, an Autobiography. Crown 8vo. 5s. General Bounce, or the Lady and the Locusts. Crown 8ro. 5s. Holmby House, a Tale of Old Northamptonshire. Crown 8vo. 5s. Good for Nothing, or All Down Hill. Crown 8vo. $6 s$.

The Queen's Maries, a Romance of Holyrood. Crown 8ro. 6s. The Interpreter, a Tale of the War. Crown 8 ro. $5 s$.

THE SIX SISTERS of the VALLEYS: an Historical Romance. By W. Bramley-Moore, M.A. Fourth Edition, with 14 Illustrations. Crown 8vo. 5s.

TALES from GREER MYTHOLOGY. BY GEORGE W. Cox, M.A. late Scholar of Trin. Coll. Oxon. Second Edition. Square 16mo. 3s. 6d.

Tales of the Gods and Heroes. By the same Author. Second Edition. Fep. 5 s.

Tales of Thebes and Argos. By the same Author. Fcp. 4s.6d.

TALES from ANCIENT GREECE. By the same Author. Being a Collective Edition of the Author's Classical Stories and Tales, complete in One Volume. Crown 8vo. 6s. $6 d$.

A MANUAL of MYTHOLOGY, in the form of Question and Answer. By the same Author. Fep. 3s.

\section{Poetry and The Drama.}

MOORE'S POETICAL WORKS, Cheapest Editions complete in 1 vol. including the Autobiographical Prefaces and Author's last Notes. Crown 8vo. ruby type, with Portrait, 6s.: People's Edition, larger type, 12s. $6 d$.

Moore's Poetical Works, as above, Library Edition, medium 8vo. with Portrait and Vignette, 14s. or in 10 vols. fcp. $3 s .6 d$. each.

MOORE'S IRISH MELODIES, Maclise's Edition, with 161 Steel Plates from Original Drawings. Super-royal 8vo. 31s. 6d.

Miniature Edition of Moore's Irish Melodies with Maclise's Designs (as above) reduced in Lithography. Imp. $16 \mathrm{mo} .10 s .6 d$.

MOORE'S IAILA ROOKH. Tenniel's Edition, with 68 Wood Engravings from original Drawings and other Illustrations. Fcp. 4to.21s.

SOUTHEY'S POETICAL WORKS, with the Author's last Corrections and copyright Additions. Lihrary Edition, in 1 vol. medium 8vo. with Portrait and Vignette, $14 s$, or in 10 vols. fcp. $3 s .6 d$. each.

LAYS of ANCIENT ROME; with Ivry and the Armada. By the Right Hon. Lord MaCaULAY. 16mo. 4s.6d.

Iord Macaulay's Lays of Ancient Rome. With 90 Illustrations on Wood, from the Antique, from Drawings by G. ScHARP. Fcp. 4to. 218.

Miniature Edition of Lord Macaulay's Lays of Ancient Rome, with the Illustrations (as above) reduced in Lithography. Imp. 16mo.10s.6d. 
MEMORIES of sOme CONTEMPORARY POETS ; with Selections from their Writings. By EMILY TAYLOR. Royal 18mo. $5 s$.

Poems. By Jean Ingelow. Thirteenth Edition. Fep. 8vo. 5s.

POEMS by Jean Ingelow. A New Edition, with nearly 100 Illustrations by Eminent Artists, engraved on Wood by the Brothers DalzIEL. Fep. 4to. 21 s.

A STORY of DOOM, and other Poems. By JeAn Ingelow. Fcp. 5s. ALICE RUSHTON, and other Poems. By Francis REYNoLds. Crown 8vo. 7s. 6 d.

A HOMEWARD RIDE, and other Poems. By C. Austen Leigh. 3s. $6 d$.

POETICAL WORKS of LETITIA ELIZABETH LANDON (L.E.L.) 2 vols. $16 \mathrm{mo}, 10 s$.

BOWDLER'S FAMILY SHAKSPEARE, cheaper Genuine Edition, complete in 1 vol. large type, with 36 Woodcut Illustrations, price 14s. or with the same Illustrations, in 6 pocket vols. $3 s$. $6 d$. each.

SHAKSPEARE'S SONNETS NEVER BEFORE INTERPRETED; his Private Friends identified; together with a recovered Likeness of Himself. By GERALD MASSEY. 8vo. 18s.

HORATII OPERA. Library Edition, with Marginal References and English Notes. Edited by the Rev. J. E. YoNGe. 8vo. $21 s$.

The IENEID of VIRGIL Translated into English Verse. By JoHN Conington, M.A. Crown 8vo. $9 s$.

ARUNDINES CAMI, sive Musarum Cantabrigiensium Lnsus canori. Collegit atque edidit H. DRURY, M.A. Editio Sexta, curavit H. J. HodGson, M.A. Crown 8vo. 7s. $6 d$.

EIGHT COMEDIES of ARISTOPHANES, viz. the Acharnians, Knights, Clouds, Wasps, Peace, Birds, Frogs, and Plutus. Translated into Rhymed Metres by LEONARD HAMPSON RUDD, M.A. 8vo. 15s.

PLAYTIME with the POETS : a Selection of the best English Poetry for the use of Children. By a LADY. Revised Edition. Crown 8vo. 5s.

The HOLY CHILD : a Poem in Four Cantos; also an Ode to Silence, and other Poems. By Stephen Jenner, M.A. Fep. 8vo. 5s.

POETICAL WORKS of JOHN EDMUND READE; with final Revision and Additions. 3 vols. fcp. $18 s$. or each vol. separately, $6 s$.

The ILIAD of HOMER TRANSLATED into BLANK VERSE. By ICHABOD CHARLES WRIGHT, M.A. 2 vols. crown 8 vo. $21 s$.

The ILIAD of HOMER in ENGLISH HEXAMETER VERSE. By J. Henry Dart, M.A. of Exeter Coll. Oxford. Square crown 8vo. 21s.

DANTE'S DIVINE COMEDY, translated in English Terza Rima by JoHN DAYMAN, M.A. [With the Italian Text, after Brunetti, interpaged.] 8vo. $21 s$.

\section{Rural Sports, \&c.}

BLAINE'S ENCYCLOP EDIA of RURAL SPORTS; Hunting, Shooting, Fishing, Racing, \&c. With above 600 Woodcuts (20 from Designs by JOII LEECH). 8v0. $42 s$. 
Col. HAWKER'S INSTRUCTIONS to YOUNG SPORTSMEN in all that relates to Guns and Shooting. Revised by the Author's Son. Square crown 8vo. with Illustrations, 18 s.

The RIFLE, its THEORY and PRACTICE. By ARTHUR WALKer (79th Highlanders), Staff. Hythe and Fleetwood Schools of Musketry. Second Edition. Crown 8vo. with 125 Woodcuts, 5 s.

The DEAD SHOT, or Sportsman's Complete Guide; a Treatise on the Use of the Gun, Dog-breaking, Pigeon-shooting, \&c. By MARKsMaN. Revised Edition. Fcp. 8vo. with Plates, 5s.

The FLY-FISHER'S ENTOMOLOGY. By AlFred Ronat.ds. With colonred Representations of the Natural and Artificial Insect. Sixth Edition: with 20 coloured Plates. 8vo. 14s.

A BOOK on ANGLING; a complete Treatise on the Art of Angling in every branch. By FrANcIS FRANCIS. Second Edition, with Portrait and 15 other Plates, plain and coloured. Post 8vo.15s.

HANDBOOK of ANGLING : Teaching Fly-fishing, Trolling, Bottomfishing, Salmon-fishing; with the Natural History of River Fish, and the best modes of Catching them. By EPHEMERA. Fcp. Woodcuts, 5 s.

The BILLIARD B00K. By Captain Crawley. With about 100 Diagrams on Steel and Wood. 8vo. 21s.

The CRICKET FIELD; or, the History and the Science of the Game of Cricket. By James Pycroft, B.A. Fourth Edition. Fep 5s.

The HORSE-TRAINER'S and SPORTSMAN'S GOIDE: with Considerations on the Duties of Grooms, on Purchasing Blood Stock, and on Veterinary Examination. By DigBY Collins. Post 8vo. $6 s$.

The HORSE'S FOOT, and HOW to KEEP IT SOUND. By W. MILEs, Esq. Ninth Edition, with Illustrations. Imperial 8vo. 12s. $6 d$.

A Plain Treatise on Horse-Shoeing. By the same Author. Post 8 vo. with Illustrations, $2 s$. $6 d$.

Stables and Stable-Fittings. By the same. Imp. 8vo. with 13 Plates, $15 s$.

Remarks on Horses' Teeth, addressed to Purchasers. By the same. Post 8vo. 1s.6d.

On DRILI and MANCEUVRES of CAVALRY, combined with Horse Artillery. By Major-Gen. Mrchase W. Smitr, C.B. 8vo. 12s.6d.

BLAINE'S VETERINARY ART; a Treatise on the Anatomy, Physiology, and Curative Treatment of the Diseases of the Horse, Neat Cattle and Sheep. Seventh Edition, revised and enlarged by C. STEEL, M.R.C.V.S.L. 8vo. with Plates and Woodcuts, $18 s$.

The HORSE: with a Treatise on Draught. By William Yodatr. New Edition, revised and enlarged. 8vo. with numerous Woodcuts, 12s. $6 d$.

The Dog. By the same Author. 8vo. with numerous Woodcuts, 6s.

The DOG in HEALTH and DISEASE. By STONEHENGE. With 70 Wood Engravings. Square crown 8vo. 10s. $6 d^{\text {. }}$ 
The GREYHOUND. By Stoneuenge. Revised Edition, with 24 Portraits of Greyhounds. Square crown 8vo. 21s.

The 0X; his Diseases and their Treatment: with an Essay on Parturition in the Cow. By J. R.DoBsor. Crown 8vo. with Illustrations, 7s. $6 d$.

Commerce, Navigation, and Mercantile Affairs.

BANGING, CURRENCY, and the EXCHANGES ; a Practical Treatise. By Arthur Crump. Post 8vo.6s.

The ELEMENTS of BANGING. By Henry Dunning MaCleod, M.A. Barrister-at-Law. Post 8vo.

[Nearly ready.

The THEORY and PRACTICE of BANIING. By the same Author. Second Edition, entirely remodelled. 2 vols. 8vo. $30 s$.

ELENENTS of MARITIME INTERNATIONAL LAW. By WILLIAM DE BURGH, B.A. of the Inner Temple, Barrister-at-Law. 8vo. 10s. 6d.

PAPERS on MARITIME LEGISLATION; with a Translation of the German Mercantile Law relating to Maritime Commerce. By ERNst EmI. WENDT. 8vo. 10 s. $6 d$.

PRACTICAL GUIDE for BRITISH SHIPMASTERS to UNITED States Ports. By Pierrepont Edwards. Post 8vo. 8s.6d.

A NATTICAL DICTIONARY, defining the Technical Language relative to the Building and Equipment of Sailing Vessels and Steamers, \&c. By Arthur Young. Second Edition; with Plates and 150 Woodcuts. 8vo. $18 s$.

A DICTIONARY, Practical, Theoretical, and Historical, of Commerce and Commercial Navigation. By J. R. M'Colloch, Esq. New and thoroughly revised Edition, in the press.

A MANUAL for NAVAL CADETS. By J. M'NeIL Bord, late Captain R.N. Third Edition; with 240 Woodcuts and 11 coloured Plates. Post 8vo.12s. $6 d$.

The LAW of NATIONS Considered as Independent Political Communities. By Travers TwISs, D.C.L. Regius Professor of Civil Law in the University of Oxford. 2 vols. 8vo. 30s. or separately, PART I. Peace, 12 s. PART II. War, $18 s$.

\section{Works of Utility and General Information.}

MODERN COOKERY for PRIVATE FAMILIES, reduced to a System

of Easy Practice in a Series of carefully-tested Receipts. By ELIzA Actor. Newly revised and enlarged Edition; with 8 Plates of Figures and 150 Woodcuts. Fep. 6 .

On FOOD and its DIGESTION; an Introduction to Dietetics. By W. Brintor, M.D. With 48 Woodcuts. Post 8vo.12s. 
WINE, the VINE, and the CELlar. By Thomas G. Shaw. Second Edition, revised and enlarged, with 32 Illustrations. 8vo. 16s.

HOW TO BREW GOOD BEER: a complete Guide to the Art of Brewing Ale, Bitter Ale, Table Ale, Brown Stout, Porter, and Table Beer. By JoHn PItr. Revised Edition. Fep. 4s. 6d.

A PRACTICAL TREATISE on BREWING; with Formulæ for Public Brewers, and Instructions for Private Families. By W. BLACK. 8vo. 10s.6d.

SHORT WHIST. By MAJOR A. Sixteenth Edition, revised, with an Essay on the Theory of the Modern Scientific Game by PROp.P. Fcp. 3s. 6d.

WHIST, WHAT TO LEAD. By CAM. Fourth Edition. $32 \mathrm{mo} .1 s$.

A HANDBOOK for READERS at the BRITISH MUSEUM. By Thомas Nichols. Post 8vo. $6 s$.

The EXECUTOR's GUIDE. By J. C. Hudson. Enlarged Edition, revised by the Author, with reference to the latest reported Cases and Acts of Parliament. Fcp. 6s.

The CABINET LAWYER ; a Popular Digest of the Laws of England, Civil, Criminal, and Constitutional. Twenty-third Edition, brought down to the close of the Parliamentary Session of 1867. Fcp. 10s. $6 d$.

The PHILOSOPHY of HEALTH; or, an Exposition of the Physiological and Sanitary Conditions conducive to Human Longevity and Happiness. By SoothwOoD SMITH, M.D. Eleventh Edition, revised and enlarged; with 113 Woodcuts. 8vo.7s. $6 d$.

HINTS to MOTHERS on the MANAGEMENT of their HEALTH during the Period of Pregnancy and in the Lying-in Room. By T. BuLL, M.D. Fep. $5 s$.

The Maternal Management of Children in Health and Eisease. By the same Author. Fcp. $5 s$.

The LAW RELATING to BENEFIT BUILDING SOCIETIES; with Practical Observations on the Act and all the Cases decided thereon; also a Form of Rules and Forms of Mortgages. By W. TIDD PRATT, Barrister. Second Edition. Fcp. $3 s .6 d$.

NOTES on HOSPITAls. By Florence Nightingale. Third Edition, enlarged; with 13 Plans. Post 4to. 18 s.

COULTHART'S DECIMAL IITTEREST TABLES at 24 Different Rates not exceeding 5 per Cent. Calculated for the use of Bankers. To which are added Commission Tables at One-Eiglith and One-Fourth per Cent. 8vo. price $15 s$.

MAONDER'S TREASURY of KNOWLEDGE and LIBRARY of Reference: comprising an English Dictionary and Grammar, Universal Gazetteer, Classical Dictionary, Chronology, Law Dictionary, a Synopsis of the Peerage, useful Tables, \&c. Revised Edition. F'cp. 10s. 6d. 
EAstrake's Hints on Household Taste .... Ebwa Rds' Shipmaster's Guide ............... Elements of Botany ....................... ELwcotr's Commentary on Ephesians ..... Lectures on Life of Christ ........ Commentary on Galatians ........ Pastoral Epist... Philippians, \&c... Thessalonians...

EnokL's Introduction to National Music .. Essays and Reviews .........................

by Mannino, Firgt and Second Szries.. EwaLd's History of Israel ..................

Fatr batre on Iron Shipbuilding .......... Falrbairs's Application of Cast and Wrought Iron to Building................ Information for Engineers.... Treatise on Mills \& Millwork

Faraar's Chapters on Language ........... FiLkin on Hosiery and Lace Manufactures Froveress's Christendom's Divisions.........

Fliedner's (Pastor) Life......................

Francis's Fishing Book ......................... (Sir P.) Mem Froude's History of Ë. _ Short Studies on Great Subjects

GAnor's Elementary Physics Giner. Crubst and Chorchill's Dolonite Moun-

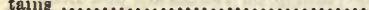

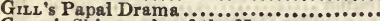

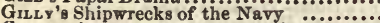
Guodeve's Elements of Mechanism ......... GoRLE's Questions on Browns's Exposition of the 39 Articles........................

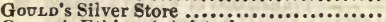

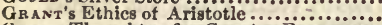
Graver Thoughts of a Country Parson ....

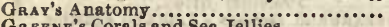

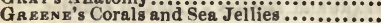
- Sponges and Animalcula ......... Grove on Correlation of Physical Forces... Gwur's Encyclopædia of Architecture ....

Handbook of Angling, by EpнвмraA

IIARE on Election of Representatives ........ H A RLEY and BAOWN's Histologlcal Demon-

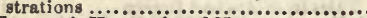

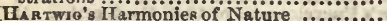
Polar World .................... Sea and it $\mathrm{Living}$ Wonders..... Tropical World

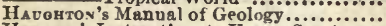
H $A$ WKEH's Instructions to Young Sportsmen

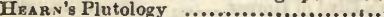

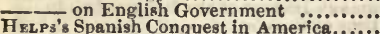
IIR \DER sON's Folk-Lore of the Northern

Counties ...............................

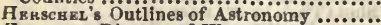

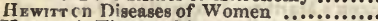

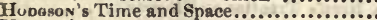

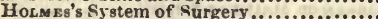
HоOK FR and WALKER-ARNoTT's British

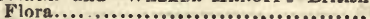
Hoperns's IIawaii ......................... Horne's Introduction to the Scriptures..... Compendium of ditto...............
Horslexy's Manual of Poisons .............. Hosk y Ns's Occasional Essays ................ How we Spent the Summer ................. Howard's Gymnastic Exercises .............. Howirr's Australian Discovery .............. Kural Life of Eneland.............. Visits to Remarkable Places.......

Honsos's Executor's Guide ................. Hogres's (W.) Manual of Geography........ Hulla s's Collection of Sacred Music ...... I,ectures on Modern Music ........ Transition Musical Lectures ..... HUM PHR Rys' Sentiments of Shakspeare ..... Horron's Studies in Parliament............

INokLow's Poems........................... Story of $\mathrm{Doom}$

Jamzson's Legends of the Saints and Martyrs....................................................... - Legends of the Monastic Orders JAMESON and EAstiakE's History of Our

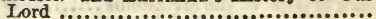

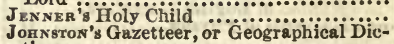

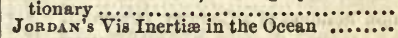

Kaliscr's Commentary on the Bible ...... Hebrew Grammar.................

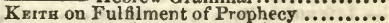

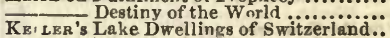
Kesteven's Domestic Medicine ............ KIRAV and SPEnce's Entomology ............

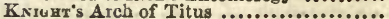

Lady's Tonr Round Monte Rosa

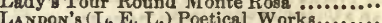
orks......... . River Plate .....................

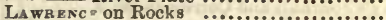

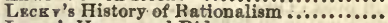
Leros's Homeward Ride.................... Leisure Hours in Town .....................

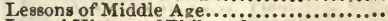

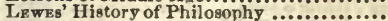
Letters of Distinguished Musicians .......... LIDDELL and Scorr's Greek-English Lexicon Tife of Abridged ditto ......... I.ife of Man Symbolised ................... InNoman's Lectures on the History of Eng-

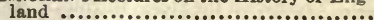

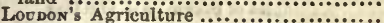
Cottage, Farm, Vilia Architecture Gardening....................... Plants ...........................

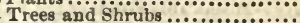

Low NDEs's Engineer's Handbook ............

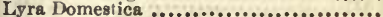

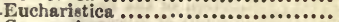
Germanica Messianica ............................. Mystica $\quad . \ldots \ldots \ldots \ldots \ldots \ldots \ldots \ldots \ldots \ldots \ldots \ldots \ldots$ Sacr 000000000000000000000000

Macauray's (Iord) Essays ................. History of England....... Jays of Ancient Rome. Miscellaneous Writings. Speeches .............. 
Sewerc's Princlples of Education ..........

Readings for Confirmation.........

Readings for Lent . . . . . . . . . . . . .

Tales and Stories.................. Ursula

Snaw's Work on Wine ......................

ShEPBRRD's Iceland $\ldots \ldots \ldots \ldots \ldots \ldots \ldots \ldots$.

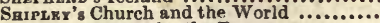

Tracts for the Day ...............

Short Whist ..............................

Sноnт's Church History ...................

Surrn's (Sournwoop) Philosophy of Health

(G.) King David ..................

Wesleyan Methodism ..........

(SxDNEx) Miscellaneous Works .....

Moral Philosophy ..........

Wit and Wisdom............

Smrrr on Cavalry Drill and Manceuvres.....

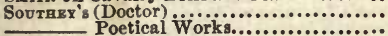

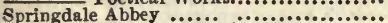

Staner's History of British Birds ..........

Stebrino's Analysis of MiLc's Logic...........

Strperen's Essays in Ecclesiastical Bio-

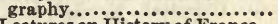

Lectures on History of France...

Straline's Secret of Hegel..................

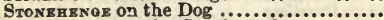
on the Greyhound.................

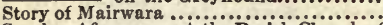
Sunday Afternoons at the Parish Church of a Scottish University City (Aberdeen)....

TArzon's (Jeremy) Works, edited by EDEN (E.) Selections from some Contemporary Poets ....................

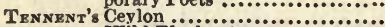

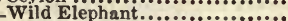

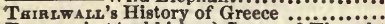

Thomson's (Archbishop) Laws of Thought (A. T.) Conspectus

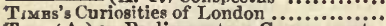

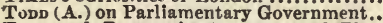

TODD and Bowman's Anatomy and Physiology of Man. ..................

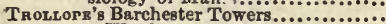

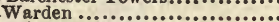

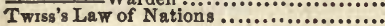

Tyndan's Lectures on Heat................ 11

Sound $\ldots \ldots \ldots \ldots \ldots \ldots$ in 11

Memoir of Farada

Unz's Dictionary of Arts, Manufactures, and Mines ..............................

VAx DrR Hozvan's Handbook of Zoology.. 11 VAvoraN's ( $\mathbf{R}_{\text {.) }}$ Revolutions in English History .................. W ay to Rest.

Warrgr on the Rifie

WARD's Workmen and W $_{\text {ages }} \ldots \ldots \ldots \ldots \ldots$ Warson's Principles and Practice of Physic W W Wraster \& WIL WELD's Florence. ........................ Wellivoton's life, by the Rev $G$. $R$.

Greme ...................................

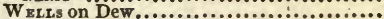
WEND's Papers on Maritime Law........... Wrst on Children's Diseases.................

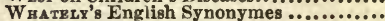
Iogic .........................

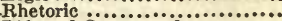
Life and Correspondence .......

Weately on the Truth of christianity.... Religious Worship

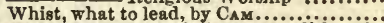
WhITs and RIDDLE's Latin-English "̈̈ictionaries ..............................

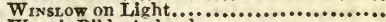
Wood's Bible Animals ......................

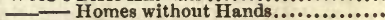
Wriont's Homer's Iliad......................

Yover's English-Greek Lexicon

Abridged ditto $\ldots . . . \ldots \ldots \ldots \ldots \ldots$

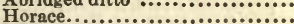

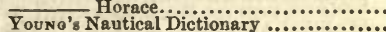

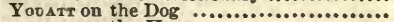
on the Horse $\ldots \ldots \ldots \ldots \ldots \ldots \ldots \ldots . . . . . . .$.

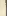




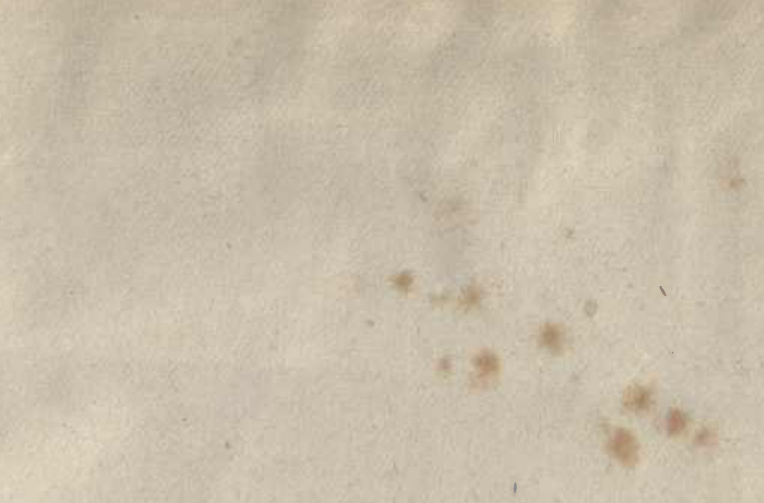


RI IURN TO DESK FROM WHICH BORROWED

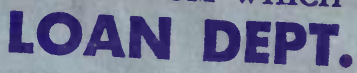

RENEWALS ONLY-TEL. NO. 642-3405

This book is due on the last date stamped below, or on the date to which renewed.

Renewed books are subject to immediate recall.

3271970 is:

RICETVED

FEP 1370 IIAM

APलD BEPस:

EEC 111975 


\section{YA 02203}


